PNNL-12008

Rev. 0

\title{
Relative Hazard Calculation Methodology
}

\author{
R. D. Stenner \\ M. K. White \\ D. L. Strenge \\ W. B. Andrews
}

February 1999

Prepared for the

Office of Science and Risk Policy

U.S. Department of Energy

Office of Environmental Management

and

Center for Risk Excellence

U.S. Department of Energy

Chicago Operations Office

Pacific Northwest National Laboratory

Richland, Washington 99352 



\section{DISCLAIMER}

This report was prepared as an account of work sponsored by an agency of the United States Government. Neither the United States Government nor any agency thereof, nor any of their employees, make any warranty, express or implied, or assumes any legal liability or responsibility for the accuracy, completeness, or usefulness of any information, apparatus, product, or process disclosed, or represents that its use would not infringe privately owned rights. Reference herein to any specific commercial product, process, or service by trade name, trademark, manufacturer, or otherwise does not necessarily constitute or imply its endorsement, recommendation, or favoring by the United States Government or any agency thereof. The views and opinions of authors expressed herein do not necessarily state or reflect those of the United States Government or any agency thereof. 


\section{DISCLAIMER}

Portions of this document may be illegible in electronic image products. Images are produced from the best available original document. 


\section{Acknowledgments}

The authors wish to acknowledge and thank Mark Gilbertson and the Department of Energy-Office of Science and Risk Policy (DOE/EM-52) for the insight to fund and promote the development of this document.

Also, a special acknowledgment and thanks go to Al Young and Mark Bollinger of the Department of Energy-Center for Risk Excellence (CRE), and the CRE Board, for identifying the need, through the development of the site risk profiles, for the methodology addressed by the document. They also provided funding and support for the application of this methodology to site-specific risk profiles, which helped to iteratively develop the methodology using real site cases.

The authors also wish to acknowledge and thank Bruce Napier (PNNL) for providing peer review and excellent technical suggestions for improving the document. 


\section{Contents}

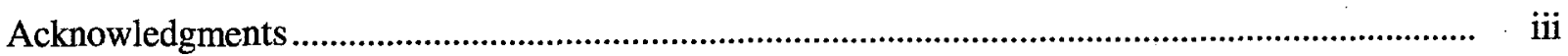

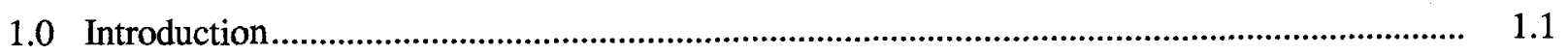

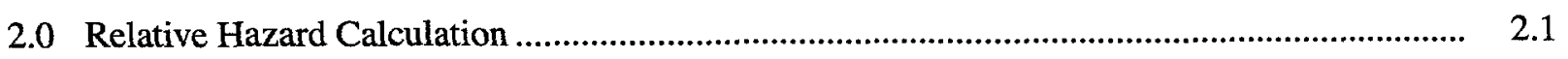

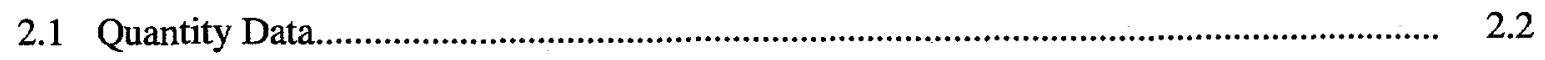

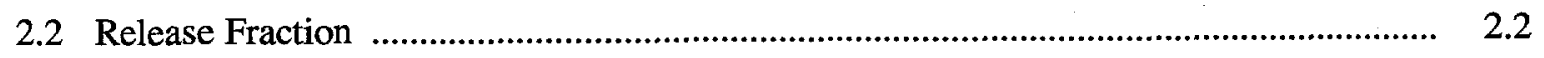

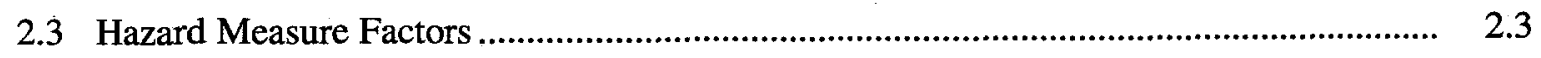

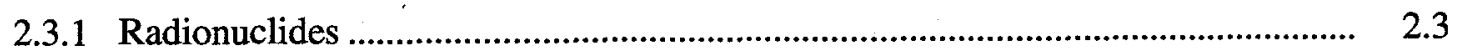

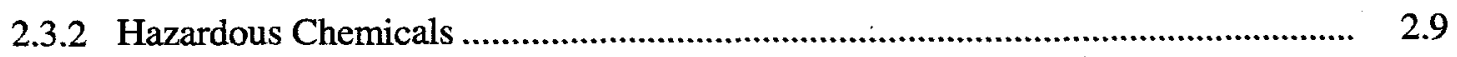

2.4 Hazard Control Factors....................................................................................... 2.10

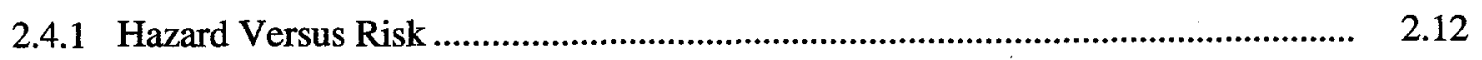

2.4.2 Factors Affecting the HC............................................................................ 2.13

2.4.3 Approach for Estimating HCs .................................................................. 2.14

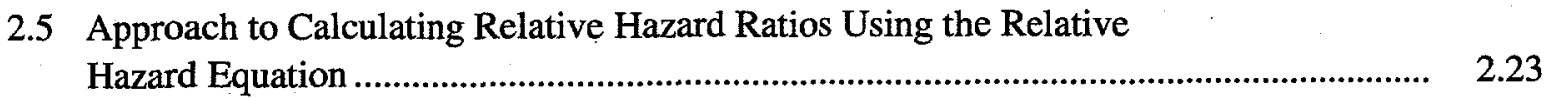

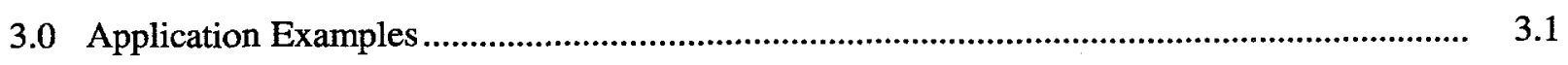

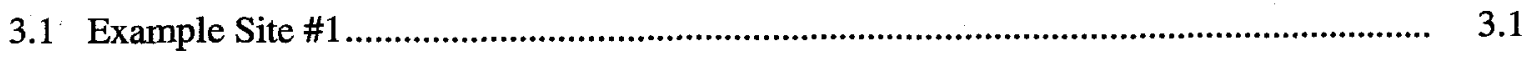

3.1.1 Surface Contamination Calculation Notes.................................................... 3.1

3.1.2 Sub-Surface Contamination Calculation Notes ............................................... 3.4

3.1.3 Waste Disposal Operations Calculation Notes .................................................. 3.6

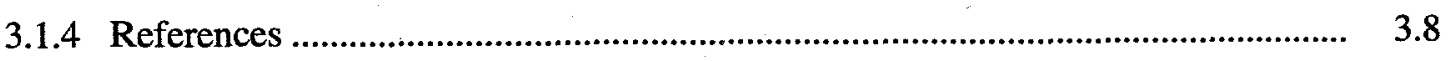




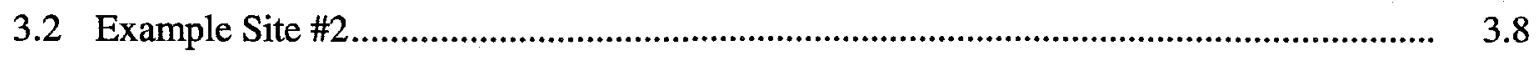

3.2.1 Nuclear Materials Calculation Notes.............................................................. 3.8

3.2.2 Transuranic Waste Calculation Notes ......................................................... 3.10

3.2.3 Low-Level Waste and Mixed Low-Level Waste Calculation Notes .................... 3.12

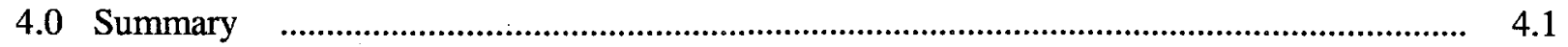

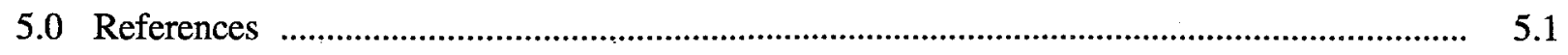




\section{Figures}

3.1 Surface Contamination Calculated for Example Site \#1 ............................................... 3.4

3.2 Sub-Surface Contamination Calculated for Example Site \#1 ........................................... 3.5

3.3 Waste Disposal Calculations for Example Site \#1 ........................................................ 3.7

3.4 Nuclear Material Relative Hazards Calculated for Example Site \#2 _.................................... 3.10

3.5 Transuranic Waste Relative Hazards Calculated for Example Site \#2 ................................... 3.12

3.6 LLW and LLMW Relative Hazards Calculated for Example Site \#2 ................................. 3.15 


\section{Tables}

2.1 Air Exposure Pathway Groups for Radionuclides ................................................... 2.5

2.2 Surface Water Exposure Pathway Groups for Radionuclides........................................... 2.6

2.3 Partition Coefficients $\left(\mathrm{K}_{\mathrm{d}} \mathrm{s}\right)$ and Derived Groundwater Transfer Coefficients Used in the Groundwater Exposure Pathway Radionuclide Categories

2.4 Groundwater-to-Surface Water Exposure Pathway Groups for Radionuclides

2.5 Fire/Explosion Exposure Pathway Groups for Radionuclides.

2.6 Direct Contact Exposure Pathway Groups for Radionuclides

2.7 Hazard Measures for Chemicals Based on Reportable Quantity

2.8 Hazard Measures Determination for Representative Constituents

2.9 Hazard Reduction Measures with Generic Hazard Control Factors

2.10 Contaminant Categories

2.11 Hanford Hazard Control Factor Parameters.

2.12 INEEL Hazard Control Factor Parameters

2.13 Rocky Flats Hazard Control Factor Parameters.

2.14 Savannah River Hazard Control Factor Parameters

3.1 Sub-Surface Inventory 


\subsection{Introduction}

In February 1997, the Center for Risk Excellence (CRE) was created and charged as a technical, field-based partner to the Office of Science and Risk Policy (EM-52). One of the initial charges to the CRE was to assist the sites in the development of "site risk profiles." These profiles were to be relatively short summaries (periodically updated) with a broad perspective on the major risk-related challenges that face the respective site. The risk profile serves as a high-level communication tool for interested internal and external parties to enhance the understanding of these risk-related challenges. The risk profile for each site has been designed to qualitatively present the following information: 1) a brief overview of the site, 2) a brief discussion on the historical mission of the site, 3) a quote from the site manager indicating the site's commitment to risk management, 4) a listing of the site's top risk-related challenges, 5) a brief discussion and detailed table presenting the site's current risk picture, 6) a brief discussion and detailed table presenting the site's future risk reduction picture, and 7) illustrations of the projected management of the relative hazards at the site. During fiscal year 1998, risk profiles for the Richland Operations Office (DOE 1998a), Nevada Operations Office (DOE 1998b), Rocky Flats Field Office (DOE 1998c), Savannah River Operations Office (DOE 1998d), and Albuquerque Operations Office (DOE 1998e) were developed, which used the methodology discussed in this report.

The illustrations were included to provide the reader of the risk profiles with a high-level mental picture to associate with all the qualitative information presented in the risk profile. This report presents the methodology developed to produce the graphics showing the relative hazard reductions that occur as a result of a site's projected risk management actions.

The term "controlling constituent" is used often in this document. Controlling constituents are defined as those radionuclides and/or hazardous chemicals in a particular waste type that tend to control its environmental impact or hazardousness of the consequences associated with the waste material. In the analysis methods discussed in this document, it is advantageous to limit the number of controlling constituents to as few as possible and still adequately represent the hazardousness of the waste material. In most risk assessments, there are usually just one or two constituents that tend to drive the risk. It is these constituents that we are calling "controlling constituents." 


\subsection{Relative Hazard Calculation}

The methodology consists of 1) using site-specific information (e.g., information from site disposition maps, site-specific Project Baseline Summaries (PBSs), and other site documents that address elements of the overall risk story for a site) and 2) applying factors from applicable site-specific risk assessment results or look-up tables to generate relative hazard $(\mathrm{RH})$ ratio values by waste type.

Relative hazard calculations are made using the following relationship of key risk-related parameters that can be extracted from the information provided for the risk profiles:

Relative Hazard $(\mathrm{RH})=\sum_{\mathrm{cc}=1}^{\mathrm{n}} \mathrm{Q}_{\mathrm{cct}} / \mathrm{Q}_{\mathrm{cct} 0} * \mathrm{RF}_{\mathrm{ccct}} / \mathrm{RF}_{\mathrm{cct} 0} * \mathrm{HMcct}_{\mathrm{c}} / \mathrm{HMcct}_{0} * \mathrm{HC}_{\mathrm{cct}} / \mathrm{HC}_{\mathrm{cct} 0}$

where $\quad Q_{\text {cct }}=$ quantity of the controlling constituents (radionuclides, in curies and hazardous chemicals, in kilograms) at time $t$ (i.e., time when specified risk management action is completed)

$\mathrm{Q}_{\mathrm{cct} 0}=$ quantity of the controlling constituents (radionuclides, in curies and hazardous chemicals, in kilograms) at time to (i.e., the original baseline or starting time)

$\mathrm{RF}_{\mathrm{cct}}=$ fraction of controlling constituent quantity that is releasable to the controlling pathway at time $\mathbf{t}$

$\mathrm{RF}_{\text {cct } 0}=$ fraction of the controlling constituent quantity that is releasable to the controlling pathway at time $t 0$

$\mathrm{HM}_{\mathrm{cct}}=$ hazard measure factor for controlling constituent and controlling pathway at time $\mathrm{t}$ (hazard measure factors from look-up tables)

$\mathrm{HM}_{\mathrm{cct} 0}=$ hazard measure factor for controlling constituent and controlling pathway at time t0 (hazard measure factors from look-up tables)

$\mathrm{HC}_{\mathrm{cct}}=$ hazard control factor for risk management control action specific at time $\mathrm{t}$ (hazard control factors may be estimated from site risk data or approximated using supplied look-up tables)

$\mathrm{HC}_{\mathrm{cct} 0}=$ hazard control factor for risk management control action specific at time to (hazard control factors may be estimated from site risk data or approximated using supplied look-up tables)

$\mathbf{n}=$ number of controlling constituents. 
Note: If only one controlling constituent is identified (highly encouraged), the equation will not need to be summed over the number of controlling constituents.

The RH equation calculates a relative ratio, which represents a hazard reduction resulting from a specified risk management action compared to a baseline. It does not calculate an absolute hazard value. At this time, the level of data available in the disposition maps and PBSs are not detailed enough to support the calculation of absolute hazard values. The current state is the baseline to which each risk management action is compared. The baseline factor is designated as time-zero (t0) in subscripts and risk management factors at subsequent times $(t)$. To compare each risk management action step with the previous risk management action time step, the baseline factors (i.e., factor ${ }_{\text {cct } 0}$ ) can simply be replaced with the corresponding previous time factor (i.e., factor $_{\text {cct-1 }}$ ). Each factor of the RH equation is discussed separately below.

\subsection{Quantity (Q) Data}

The best available site-specific quantity data should be used when calculating the RH ratios. In order for the RH ratios to be comparable across the different waste types, the quantity data should be specific to each controlling constituent and should be provided in units of curies for radionuclides or grams for hazardous chemicals. If exact amounts of each controlling constituent are not available, rough estimates of the fraction of each controlling constituent contained in the total waste quantity can be made. These fractions can then be used to adjust the total waste quantity to estimate the quantity of each respective controlling constituent. If controlling constituent quantity data in curies (radionuclides) or grams (hazardous chemicals) are just not available and it is not possible to estimate the fractions of each controlling constituent in the total waste quantity, the total waste quantity of each waste type can be used as a rough surrogate, provided that units of this quantity remain the same through out the analysis of the respective waste type. However, without controlling constituent quantities, the RH result would generally be non-comparable across waste types. The RH ratios may not be accurate for risk management actions that involve treatment of the controlling constituent(s).

\subsection{Release Fraction (RF)}

In some cases, the total quantity of a controlling constituent is not all releasable to the controlling exposure pathway of concern (i.e., dominant exposure pathway). In these cases, a release fraction (i.e., the fraction of the total quantity of the controlling constituent that is releasable to the controlling pathway) should be provided for use in the RH equation to adjust the quantity. Use of a release fraction allows only the fraction of the controlling constituent quantity that can actually be released to the exposure pathway to be considered. If all of the controlling constituent quantities are available for release to the controlling exposure pathway, which is true for many waste type situations, the RF factor can be assigned a value of 1 . 


\subsection{Hazard Measure (HM) Factors}

The HM considers the inherent toxicity or carcinogenic potential of the controlling contaminants identified, as well as its potential to expose members of the public through various exposure pathways. Because constituents then are determined a priori, the HM factors, along with $Q$ data, is probably one of the least subjective of the RH equation factors. The HM factor look-up tables are provided.

The HM factors were derived differently for radionuclides and chemicals. Chemical HMs were based directly on the reportable quantities (RQs) of 40 CFR Part 302, "Designation, Reportable Quantities, and Notification." Radionuclide HMs were determined for five exposure pathways using ICRP-30 dose calculation methods and near-field exposure modeling assumptions. Derivation of these radionuclide HMs was based on a method developed for the Modified Hazard Ranking System (Hawley and Napier 1985; Hawley et al. 1986; Stenner et al. 1986). Because radionuclide and chemical HMs are determined differently, details of the two methods and differences between them are discussed below.

\subsubsection{Radionuclides}

The HM for radionuclides are similar to an exposure pathway-specific dose factor although the modeling is not detailed enough to provide an absolute dose estimate. The Modified Hazard Ranking System (MHRS), the original use of radionuclide HMs, was developed to work within the framework of the EPA's Hazard Ranking System (HRS) (EPA 1982). However, the MHRS also provides a more appropriate treatment of radionuclides in ranking mixed waste sites for the National Priority List under the Comprehensive Environmental Response, Compensation, and Liability Act (CERCLA). Like the MHRS and HRS, radionuclides are evaluated under five potential exposure pathways: air, surface water, groundwater, fire/explosion, and direct contact.

Designed for generic application anywhere the HRS could be used, the MHRS included a limited suite of radionuclides and used the ICRP Publication 2 (ICRP 1959) "critical organ" concept in assigning a potential "hazard ranking" to radionuclides. Like the MHRS-based factors, however, the RH-based HM factors are based upon near-field scenarios. In a near-field scenario, interest is focused on the doses an individual could receive at a particular location as a result of initial contamination or external sources (i.e., buried solid waste, contaminated soil, contaminated water, or contamination in air). ${ }^{(a)}$ Near-field assumptions were used, since the basic difference between near-field and far-field scenarios is dilution. In an RH analysis, the affect of dilution distance can be accounted for in the hazard control (HC) parameter associated with relocation of material further from a receptor.

(a) This differs from a far-field scenario, defined as determining impacts of a particular release of radioactive or hazardous material into a wide environment, such as the dose from releases from a stack to individuals or populations downwind. 
While the MHRS approach was retained, several enhancements were made to the HM factors presented for use in the RH calculations:

- Additional radionuclides are included. Like the MHRS-based factors, the RH-based factors are generally limited to radionuclides with a half-life of 1 year or greater, unless they were specifically noted as being potentially important in one of the waste materials being considered.

- The dose calculation methodology was updated to ICRP Publication 30 (ICRP 1979), using the GENII computer codes (Napier et al. 1988a; 1988b; 1988c) to perform updated calculations for the five exposure pathways. Radionuclide HMs are now based upon effective dose equivalent (EDE) rather than critical organ dose.

- The methodology used to produce the RH-based HM values utilized default inputs of the GENII code, and, for the groundwater exposure pathway, used groundwater transfer partition coefficients $\left(\mathrm{K}_{\mathrm{d}}\right)$ from Serne and Wood (1990).

Descriptions of the exposure assumptions and radionuclide categories for each of the five exposure pathways are provided in the sections below, along with the respective HM factor look-up tables. In each exposure pathway table, radionuclides are categorized by the approximate dose received per unit concentration. Each category differs from the others by approximately an order of magnitude in the "relative dose impact." All exposure-pathway-specific HM-factor tables have been normalized, so that the highest category is $\mathrm{V}$ and the lowest is 0 , corresponding to the exponent of the value of the HM factor assigned to each category (i.e., category $V$ has an $\mathrm{HM}$ value of 100,000 , while category 0 has an $\mathrm{HM}$ value of 1 ).

\subsubsection{Air Exposure Pathway}

This is a chronic exposure pathway that primarily poses long-term, large-scale risks to the public. Assumptions are that the exposed individual:

- lives continuously in contaminated air (chronic inhalation)

- is continuously exposed to external radiation from radionuclides deposited on the ground surface

- is continuously immersed in the airborne radioactive plume.

The values of the HM factor for the air exposure pathway are given in Table 2.1 for selected radionuclides. 
Table 2.1. Air Exposure Pathway Groups for Radionuclides

\begin{tabular}{|c|c|c|}
\hline Category & $\begin{array}{c}\text { Hazard } \\
\text { Measure (HM) }\end{array}$ & Radionuclide Grouping \\
\hline $\mathrm{V}$ & $10^{5}$ & ${ }^{22} \mathrm{Na},{ }^{54} \mathrm{Mn},{ }^{60} \mathrm{Co},{ }^{94} \mathrm{Nb},{ }^{125} \mathrm{Sb},{ }^{134} \mathrm{Cs},{ }^{137} \mathrm{Cs},{ }^{152} \mathrm{Eu},{ }^{154} \mathrm{Eu}$ \\
\hline IV & $10^{4}$ & $\begin{array}{l}{ }^{155} \mathrm{Eu},{ }^{232} \mathrm{Th},{ }^{233} \mathrm{U},{ }^{234} \mathrm{U},{ }^{235} \mathrm{U},{ }^{238} \mathrm{U},{ }^{237} \mathrm{~Np},{ }^{239} \mathrm{~Np},{ }^{238} \mathrm{Pu},{ }^{239} \mathrm{Pu}, \\
{ }^{240} \mathrm{Pu},{ }^{241} \mathrm{Am},{ }^{243} \mathrm{Cm},{ }^{244} \mathrm{Cm},{ }^{245} \mathrm{Cm}\end{array}$ \\
\hline III & $10^{3}$ & ${ }^{10} \mathrm{Be},{ }^{36} \mathrm{Cl},{ }^{109} \mathrm{Cd},{ }^{129} \mathrm{I},{ }^{241} \mathrm{Pu},{ }^{226} \mathrm{Ra},{ }^{242} \mathrm{Cm},{ }^{252} \mathrm{Cf}$ \\
\hline$\Pi$ & 100 & ${ }^{55} \mathrm{Fe},{ }^{59} \mathrm{Ni},{ }^{90} \mathrm{Sr},{ }^{93} \mathrm{Mo},{ }^{99} \mathrm{Tc},{ }^{147} \mathrm{Pm}$ \\
\hline I & 10 & ${ }^{14} \mathrm{C},{ }^{135} \mathrm{Cs},{ }^{151} \mathrm{Sm}$ \\
\hline 0 & 1 & ${ }^{3} \mathrm{H},{ }^{63} \mathrm{Ni}$ \\
\hline
\end{tabular}

\subsubsection{Surface-Water Exposure Pathway}

This is a chronic exposure pathway that primarily poses long-term risks to public users of local surface water sources. Assumptions are that the exposed individual:

- eats food irrigated with contaminated surface water, at an irrigation rate of $150 \mathrm{~L} / \mathrm{m}^{2} / \mathrm{mo}$ for $6 \mathrm{mo} / \mathrm{y}$

- eats fish from the contaminated water

- is exposed to external radiation from contaminated sediments along the bank

- gets drinking water from the contaminated surface water.

Resuspension and external radiation from radionuclides deposited on the soil from irrigation are not considered. The values of the HM factor for the surface-water exposure pathway are given in Table 2.2 for selected radionuclides.

\subsubsection{Groundwater-to-Surface-Water Exposure Pathway}

This is a chronic exposure pathway that primarily poses long-term risks to public users of the local surface water sources. Groundwater is assumed to connect with surface water through infiltration, and exposure is via the surface water exposure pathway. No direct groundwater exposure via groundwater wells is assumed. Assumptions are that the exposed individual:

- eats food irrigated with surface water contaminated via connection with groundwater, at an irrigation rate of $150 \mathrm{~L} / \mathrm{m}^{2} / \mathrm{mo}$ for $6 \mathrm{mo} / \mathrm{y}$

- eats fish from the contaminated water 
Table 2.2. Surface Water Exposure Pathway Groups for Radionuclides

\begin{tabular}{|c|c|c|}
\hline Category & $\begin{array}{c}\text { Hazard } \\
\text { Measure (HM) }\end{array}$ & Radionuclide Grouping \\
\hline $\mathrm{V}$ & $10^{5}$ & ${ }^{134} \mathrm{Cs},{ }^{137} \mathrm{Cs},{ }^{237} \mathrm{~Np}$ \\
\hline IV & $10^{4}$ & ${ }^{129} \mathrm{I},{ }^{135} \mathrm{Cs},{ }^{226} \mathrm{Ra},{ }^{232} \mathrm{Th},{ }^{241} \mathrm{Am},{ }^{243} \mathrm{Cm},{ }^{244} \mathrm{Cm},{ }^{245} \mathrm{Cm},{ }^{252} \mathrm{Cf}$ \\
\hline III & $10^{3}$ & $\begin{array}{l}{ }^{14} \mathrm{C},{ }^{22} \mathrm{Na},{ }^{36} \mathrm{Cl},{ }^{60} \mathrm{Co},{ }^{109} \mathrm{Cd},{ }^{152} \mathrm{Eu},{ }^{154} \mathrm{Eu},{ }^{233} \mathrm{U},{ }^{234} \mathrm{U},{ }^{235} \mathrm{U}, \\
{ }^{238} \mathrm{U},{ }^{239} \mathrm{~Np},{ }^{238} \mathrm{Pu},{ }^{239} \mathrm{Pu},{ }^{240} \mathrm{Pu},{ }^{242} \mathrm{Cm}\end{array}$ \\
\hline II & 100 & $\begin{array}{l}{ }^{10} \mathrm{Be},{ }^{54} \mathrm{Mn},{ }^{55} \mathrm{Fe},{ }^{63} \mathrm{Ni},{ }^{90} \mathrm{Sr},{ }^{94} \mathrm{Nb},{ }^{99} \mathrm{Tc},{ }^{125} \mathrm{Sb},{ }^{147} \mathrm{Pm},{ }^{151} \mathrm{Sm}, \\
{ }^{155} \mathrm{Eu},{ }^{241} \mathrm{Pu}\end{array}$ \\
\hline $\mathrm{I}$ & 10 & ${ }^{59} \mathrm{Ni},{ }^{93} \mathrm{Mo}$ \\
\hline 0 & 1 & ${ }^{3} \mathrm{H}$ \\
\hline
\end{tabular}

- is exposed to external radiation from contaminated sediments along the bank

- gets drinking water from the contaminated surface water.

Resuspension and external radiation from radionuclides deposited on the soil from irrigation are not considered.

The groundwater-to-surface-water exposure pathway radionuclide categories were adjusted for the tendency of radionuclides to adsorb to soil particles (partition coefficient, $K_{d}$ ) during groundwater transport. Partition coefficients were obtained (Serne and Wood 1990) and converted to groundwater transfer coefficients from 1 to 100 (Hawley and Napier 1985; Hawley et al. 1986) to be consistent with the multiplicative $\mathrm{RH}$ strategy. The $\mathrm{K}_{\mathrm{d}}$ values used for each radionuclide and the derived groundwater transfer coefficients are shown in Table 2.3. The HM factor for groundwater does not consider the time it takes the radionuclide to move through the vadose zone to the saturated zone and to a point where it could fit the near-field scenario. The values of the HM factor for the groundwater-to-surface-water exposure pathway are given in Table 2.4 for selected radionuclides.

\subsubsection{Fire/Explosion Pathway}

The fire/explosion pathway is also intended to represent non-energetic acute releases resulting from facility accident sequences. This acute exposure pathway primarily poses near-term, large-scale public health risks. Assumptions are as follows:

- Exposure lasts only a short time, approximately 0.5 hour, with the exposed individual at the center line of the released plume.

- The only relevant pathway is inhalation; to account for the high concentration of material in the plume, it was modeled as resuspension with a mass loading of $1 \mathrm{~g} / \mathrm{m}^{3}$. 
Table 2.3. Partition Coefficients $\left(\mathrm{K}_{\mathrm{d}} \mathrm{s}\right)$ and Derived Groundwater Transfer Coefficients Used in the Groundwater Exposure Pathway Radionuclide Categories

\begin{tabular}{|c|c|c|}
\hline Constituent/Radionuclide & $\mathbf{K}_{\mathbf{d}}$ & $\begin{array}{c}\text { Groundwater Transfer } \\
\text { Coefficient }\end{array}$ \\
\hline${ }^{3} \mathrm{H}$ & $0^{\text {(a) }}$ & 100 \\
\hline $\mathrm{Be}$ & $30^{(b)}$ & 3 \\
\hline${ }^{14} \mathrm{C}$ & $0^{(a)}$ & 100 \\
\hline $\mathrm{Na}$ & $3^{(a)}$ & 33 \\
\hline $\mathrm{Cl}$ & $0^{(a)}$ & 100 \\
\hline $\mathrm{Mn}$ & $20^{(\mathrm{a})}$ & 5 \\
\hline $\mathrm{Fe}$ & $20^{(a)}$ & 5 \\
\hline $\mathrm{Co}$ & $10^{(\mathrm{a})}$ & 10 \\
\hline $\mathrm{Ni}$ & $15^{(\mathrm{a})}$ & 7 \\
\hline $\mathrm{Sr}$ & $10^{(\mathrm{a})}$ & 10 \\
\hline $\mathrm{Sb}$ & $0^{(\mathrm{b})}$ & 100 \\
\hline $\mathrm{Nb}$ & $100^{(\mathrm{b})}$ & 1 \\
\hline Mo & $0^{(a)}$ & 100 \\
\hline Tc & $0^{(a)}$ & 100 \\
\hline $\mathrm{Cd}$ & $15^{(\mathrm{a})}$ & 7 \\
\hline $\mathrm{I}$ & $0^{(a)}$ & 100 \\
\hline Cs & $50^{(\mathrm{a})}$ & 2 \\
\hline Lanthanides Eu, Pm, Sm & $50^{(a)}$ & 2 \\
\hline $\mathrm{Ra}$ & $20^{(\mathrm{a})}$ & 5 \\
\hline Th & $50^{(a)}$ & 2 \\
\hline $\mathrm{U}$ & $0^{(a)}$ & 100 \\
\hline $\mathrm{Np}$ & $3^{(a)}$ & 33 \\
\hline $\mathrm{Pu}$ & $100^{(\mathrm{a})}$ & 1 \\
\hline $\mathrm{Am}, \mathrm{Cm}$ & $100^{(a)}$ & 1 \\
\hline $\mathrm{Ac}, \mathrm{Cf}$ & $100^{(\mathrm{b})}$ & 1 \\
\hline \multicolumn{3}{|l|}{$\begin{array}{l}\text { (a) Serne and Wood (1990). } \\
\text { (b) Serne (1994). }\end{array}$} \\
\hline
\end{tabular}


Table 2.4. Groundwater-to-Surface Water Exposure Pathway Groups for Radionuclides

\begin{tabular}{|c|c|c|}
\hline Category & $\begin{array}{c}\text { Hazard } \\
\text { Measure (HM) }\end{array}$ & Radionuclide Grouping \\
\hline $\mathrm{V}$ & $10^{5}$ & ${ }^{237} \mathrm{~Np}$ \\
\hline IV & $10^{4}$ & ${ }^{129} \mathrm{I}$ \\
\hline III & $10^{3}$ & $\begin{array}{l}{ }^{14} \mathrm{C},{ }^{36} \mathrm{Cl},{ }^{134} \mathrm{Cs},{ }^{137} \mathrm{Cs},{ }^{232} \mathrm{Th},{ }^{233} \mathrm{U},{ }^{234} \mathrm{U},{ }^{235} \mathrm{U},{ }^{238} \mathrm{U},{ }^{239} \mathrm{~Np}, \\
{ }^{241} \mathrm{Am}\end{array}$ \\
\hline III & 100 & ${ }^{22} \mathrm{Na},{ }^{60} \mathrm{Co},{ }^{99} \mathrm{Tc},{ }^{125} \mathrm{Sb},{ }^{135} \mathrm{Cs},{ }^{226} \mathrm{Ra},{ }^{243} \mathrm{Cm},{ }^{244} \mathrm{Cm},{ }^{245} \mathrm{Cm}$, \\
\hline $\mathrm{I}$ & 10 & $\begin{array}{l}{ }^{54} \mathrm{Mn}, \\
{ }^{542} \mathrm{Cm}\end{array}$ \\
\hline 0 & 1 & ${ }^{3} \mathrm{H},{ }^{10} \mathrm{Be},{ }^{59} \mathrm{Ni},{ }^{63} \mathrm{Ni},{ }^{94} \mathrm{Nb},{ }^{93} \mathrm{Mo},{ }^{147} \mathrm{Pm},{ }^{151} \mathrm{Sm},{ }^{155} \mathrm{Eu},{ }^{241} \mathrm{Pu}$ \\
\hline
\end{tabular}

The values of the HM for the fire/explosion exposure pathway are given in Table 2.5 for key radionuclides.

Table 2.5. Fire/Explosion Exposure Pathway Groups for Radionuclides

\begin{tabular}{|c|c|c|}
\hline Category & $\begin{array}{c}\text { Hazard } \\
\text { Measure (HM) }\end{array}$ & \multicolumn{1}{|c|}{ Radionuclide Grouping } \\
\hline V & $10^{5}$ & ${ }^{232} \mathrm{Th},{ }^{233} \mathrm{U},{ }^{234} \mathrm{U},{ }^{235} \mathrm{U},{ }^{238} \mathrm{U},{ }^{237} \mathrm{~Np},{ }^{238} \mathrm{Pu},{ }^{239} \mathrm{Pu},{ }^{240} \mathrm{Pu}$, \\
\hline IV & 10 & $\mathrm{Am},{ }^{243} \mathrm{Cm},{ }^{244} \mathrm{Cm},{ }^{245} \mathrm{Cm},{ }^{452} \mathrm{Cf}$ \\
\hline III & $1{ }^{22} \mathrm{Na},{ }^{54} \mathrm{Mn},{ }^{60} \mathrm{Co},{ }^{94} \mathrm{Nb},{ }^{125} \mathrm{Sb},{ }^{134} \mathrm{Cs},{ }^{137} \mathrm{Cs},{ }^{152} \mathrm{Eu},{ }^{154} \mathrm{Eu}$, \\
\hline II & 100 & ${ }^{226} \mathrm{Ra},{ }^{241} \mathrm{Pu},{ }^{242} \mathrm{Cm}$ \\
\hline I & 10 & ${ }^{10} \mathrm{Be},{ }^{90} \mathrm{Sr},{ }^{109} \mathrm{Cd},{ }^{129} \mathrm{I},{ }^{155} \mathrm{Eu},{ }^{239} \mathrm{~Np}$ \\
\hline 0 & 1 & ${ }^{14} \mathrm{C},{ }^{93} \mathrm{Mo},{ }^{99} \mathrm{Tc},{ }^{135} \mathrm{Cs},{ }^{149} \mathrm{Pm},{ }^{151} \mathrm{Nm},{ }^{63} \mathrm{Ni}$ \\
\hline
\end{tabular}

\subsubsection{Direct Contact Exposure Pathway}

This is an acute exposure pathway that primarily poses near-term risks to individual workers or members of the public. Assumptions are as follows:

- The exposed individual is in direct contact with the material for a short period of time, approximately 1 hour, while digging or otherwise creating loose material airborne.

- Exposure pathways are inhalation, external exposure, and resuspension of loose material with mass loading of $0.0001 \mathrm{~g} / \mathrm{m}^{3}$. 
The values of the HM factor for the direct contact exposure pathway are given in Table 2.6 for selected radionuclides.

Table 2.6. Direct Contact Exposure Pathway Groups for Radionuclides

\begin{tabular}{|c|c|c|}
\hline Category & $\begin{array}{c}\text { Hazard } \\
\text { Measure }(\mathrm{HM})\end{array}$ & Radionuclide Grouping \\
\hline $\mathrm{V}$ & $10^{5}$ & ${ }^{22} \mathrm{Na},{ }^{54} \mathrm{Mn},{ }^{60} \mathrm{Co},{ }^{94} \mathrm{Nb},{ }^{125} \mathrm{Sb},{ }^{134} \mathrm{Cs},{ }^{137} \mathrm{Cs},{ }^{152} \mathrm{Eu},{ }^{154} \mathrm{Eu}$ \\
\hline IV & $10^{4}$ & $\begin{array}{l}{ }^{155} \mathrm{Eu},{ }^{232} \mathrm{Th},{ }^{233} \mathrm{U},{ }^{234} \mathrm{U},{ }^{235} \mathrm{U},{ }^{238} \mathrm{U},{ }^{237} \mathrm{~Np},{ }^{239} \mathrm{~Np},{ }^{238} \mathrm{Pu},{ }^{239} \mathrm{Pu}, \\
{ }^{240} \mathrm{Pu},{ }^{241} \mathrm{Am},{ }^{243} \mathrm{Cm},{ }^{244} \mathrm{Cm},{ }^{245} \mathrm{Cm},{ }^{252} \mathrm{Cf}\end{array}$ \\
\hline III & $10^{3}$ & ${ }^{109} \mathrm{Cd},{ }^{129} \mathrm{I},{ }^{226} \mathrm{Ra},{ }^{241} \mathrm{Pu},{ }^{242} \mathrm{Cm}$ \\
\hline II & 100 & ${ }^{10} \mathrm{Be},{ }^{36} \mathrm{Cl},{ }^{55} \mathrm{Fe},{ }^{59} \mathrm{Ni},{ }^{90} \mathrm{Sr},{ }^{93} \mathrm{Mo}$ \\
\hline $\mathrm{I}$ & 10 & ${ }^{14} \mathrm{C},{ }^{63} \mathrm{Ni},{ }^{99} \mathrm{Tc},{ }^{135} \mathrm{Cs},{ }^{147} \mathrm{Pm},{ }^{151} \mathrm{Sm}$ \\
\hline 0 & 1 & ${ }^{3} \mathrm{H}$ \\
\hline
\end{tabular}

\subsubsection{Hazardous Chemicals}

The HM factor values for hazardous chemicals are based on the RQs of 40 CFR Part 302.4, "Designation of Hazardous Substances." According to the EPA, "RQs represent a determination only of possible or potential harm, not that releases of a particular amount of a hazardous substances will necessarily be harmful to the public health or welfare or to the environment." The RQs provide a simple, readily available method of comparing the potential hazard from a specific set of chemicals.

The RQ-derived HMs for hazardous chemicals are fundamentally different from the HMs for radionuclides in that the RQs are not exposure-pathway specific. Their primary criteria for evaluation are aquatic toxicity, mammalian toxicity (oral, dermal, and inhalation), ignitability, reactivity, chronic toxicity, and potential carcinogenicity.

The HMs for chemicals were derived from the RQs as shown in Table 2.7. An adjustment was made to maintain a multiplicative scheme for the RH strategy. Relationships between the various RQs and HMs are maintained by this adjustment.

Table 2.7. Hazard Measures for Chemicals Based on Reportable Quantity

\begin{tabular}{|c|c|c|}
\hline Category & RQ & HM \\
\hline A & 1 & 1000 \\
\hline B & 10 & 100 \\
\hline C & 100 & 10 \\
\hline D & 1000 & 1 \\
\hline E & 5000 & 0.5 \\
\hline
\end{tabular}


Not all chemicals identified for the various DOE facilities and areas will have RQs listed in 40 CFR 302. Some HM values were derived by comparison to similar chemicals. When no values of RQ are available for a specific key chemical, surrogate values of $\mathrm{HM}$ can be developed using RQ values from a chemical with similar transport $\left(\mathrm{K}_{\mathrm{d}}, \mathrm{K}_{\mathrm{oc}}, \mathrm{K}_{\mathrm{ow}}\right.$, solubility limit, etc.) and toxicity (e.g., slope factors and reference doses). Transport and toxicity parameter values can be reviewed using the MultimediaModeling Environmental Database Editor (Warren and Strenge 1994), which accesses the Multimedia Environmental Pollution Assessment System (MEPAS) database (Strenge and Peterson 1989). Table 2.8 provides a list of constituents of possible importance to DOE sites and indicates the use of surrogate chemicals in several instances. The table lists current RQ values from 40 CFR 302 for several chemicals, with $\mathrm{HM}$ values determined using the convention of Table 2.7. For those chemicals not included in 40 CFR 302 , the estimated HM is given with an indication of the basis. For example, values for the alcohols ethanol and isopropanol are set to the value for methanol because of chemical similarity. The $\mathrm{HM}$ values for benzo(b)fluoranthene and benzo(k)fluoranthene were estimated from the HM of benzo(a)pyrene and the toxicity equivalence among the three compounds. From the MEPAS database, the oral slope factors for the three chemicals are:

$$
\begin{array}{ll}
\text { benzo(a)pyrene } & 7.3 \mathrm{~kg}-\mathrm{d} / \mathrm{mg} \\
\text { benzo(b)fluoranthene } & 0.73 \mathrm{~kg}-\mathrm{d} / \mathrm{mg} \\
\text { benzo(k)fluoranthene } & 0.073 \mathrm{~kg}-\mathrm{d} / \mathrm{mg}
\end{array}
$$

The HM for benzo(a)pyrene is multiplied by the chemical oral slope factor and divided by the benzo(a)pyrene slope factor to estimate the HM for the chemical. The inorganic chemicals in the list are assumed to be in ionic form. Some of these are expected to be in relatively non-toxic forms in the environment (e.g., sodium, potassium, magnesium, and nitrate) and have $\mathrm{HM}$ values set to the minimum value $(0.5)$ from Table 2.7.

\subsection{Hazard Control Factors}

The hazard control (HC) factors represent the worth, in terms of reduction in hazard, of specific risk management actions. These actions include

- risk management activities such as vitrification or grouting of waste materials

- separation, reduction and/or removal of specific constituents from a waste stream

- relocation of waste material away from receptors or vulnerable pathways

- repackaging and/or stabilization of waste material.

In calculating the RH of a waste type at a site, it is recommended that these $\mathrm{HC}$ factors be estimated from existing risk assessment data, where possible. In many cases, there will be specific risk assessments for which generalizations can be made to roughly estimate the worth of a specific risk management action. Often, there are risk estimates for specified accident conditions in a Safety Analysis Report (SAR) 
Table 2.8. Hazard Measures Determination for Representative Constituents

\begin{tabular}{|c|c|c|c|c|}
\hline CAS & Name & Final RQ & HM & HM Basis \\
\hline 56235 & Carbon Tetrachloride & 10 & 100 & RQ \\
\hline 67561 & Methanol & 5000 & 0.5 & $\mathrm{RQ}$ \\
\hline 64175 & Ethanol & - & 0.5 & Methanol HM \\
\hline 67630 & Isopropanol & -- & 0.5 & Methanol HM \\
\hline 75058 & Acetonitrile & 5000 & 0.5 & $\mathrm{RQ}$ \\
\hline 91203 & Naphthalene & 100 & 10 & RQ \\
\hline 91576 & 2-Methylnaphthalene & -- & 10 & Naphthalene HM \\
\hline 107211 & Ethylene glycol & 5000 & 0.5 & $\mathrm{RQ}$ \\
\hline 110543 & Hexanes & 5000 & 0.5 & $\mathrm{RQ}$ \\
\hline 117817 & Bis(2-ethylhexyl)phthalate & 100 & 10 & RQ \\
\hline 126738 & Tributylphosphate & -- & 10 & Tetrachloroethylene HM \\
\hline 127184 & Tetrachloroethylene & 100 & $\overline{10}$ & $\mathrm{RQ}$ \\
\hline 79016 & Trichloroethylene & 100 & 10 & $\mathrm{RQ}$ \\
\hline 50328 & Benzo(a)pyrene & 1 & 1000 & $\mathrm{RQ}$ \\
\hline 205992 & Benzo(b)fluoranthene & -- & 100 & $\begin{array}{l}\text { Benzo(a)pyrene } \mathrm{HM} \text { and toxicity } \\
\text { equivalence }\end{array}$ \\
\hline 207089 & Benzo(k)fluoranthene & -- & 10 & $\begin{array}{l}\text { Benzo(a)pyrene } \mathrm{HM} \text { and toxicity } \\
\text { equivalence }\end{array}$ \\
\hline 1809194 & Dibutyl Phosphate & -- & 10 & Tetrachloroethylene $\mathrm{HM}$ \\
\hline 6834920 & Silica & -- & 0.5 & Minimum HM value \\
\hline 7429905 & Aluminum ion & 5000 & 0.5 & RQ for aluminum sulfate \\
\hline 7439987 & Molybdenum ion & -- & 1 & HM value for chromium III and VI \\
\hline 7440393 & Barium & 1000 & 1 & $\mathrm{RQ}$ \\
\hline 7440473 & Chromium VI ion & 1000 & 1 & RQ for chromic acetate and sulfate \\
\hline 7440611 & Uranium ion & 100 & 10 & RQ for uranyl acetate and nitrate \\
\hline 7440622 & Vanadium ion & 1000 & 1 & RQ for vanadium compounds \\
\hline 7440677 & Zirconium ion & 5000 & 0.5 & RQ for zirconium compounds \\
\hline 7440702 & Calcium ion & -- & 0.5 & Minimum HM value \\
\hline 7447407 & Potassium ion & -- & 0.5 & Minimum HM value \\
\hline 7447418 & Lithium ion & 10 & 100 & RQ for lithium chromate \\
\hline 7601549 & Phosphate ion & 5000 & 0.5 & RQ for phosphoric acid \\
\hline 7647145 & Sodium ion & - & 0.5 & Minimum HM value \\
\hline 7782414 & Fluoride ion & 1000 & 1 & RQ for fluorides of sodium and zinc \\
\hline 7786303 & Magnesium ion & -- & 0.5 & Minimum HM value \\
\hline 12808798 & Sulfate ion & -- & 0.5 & Minimum HM value \\
\hline 14797558 & Nitrate ion & - & 0.5 & Minimum HM value \\
\hline 15438310 & Iron ion & 1000 & 1 & RQ for ferric chloride and sulfate \\
\hline 16065831 & Chromium III ion & 1000 & 1 & RQ for chromus chloride \\
\hline 14797650 & Nitrite ion & 1000 & 1 & RQ for sodium nitrite \\
\hline 7440360 & Antimony ion & 1000 & 1 & RQ for common antimony salts \\
\hline
\end{tabular}


or safety basis document that can be examined to get a rough estimate of the worth of a specific action. In cases where no such risk assessment data are available, HC look-up tables are provided to use in estimating the $\mathrm{HC}$ factor.

The HC factor is used to assess changes in the relative hazard of a contaminant or waste based on changes in its physical condition or location due to waste management or environmental restoration actions. The HC factor for a specific hazard reduction measure (e.g., capping) represents the reduction in hazard associated with that measure (i.e., the post-action hazard divided by the pre-action hazard). In conjunction with the other factors representing contaminant inventory, the nature of the contaminant, and potential contaminant exposure mechanism, the $\mathrm{HC}$ factor allows evaluation of the potential reduction in hazard associated with a variety of potential waste management or environmental restoration actions.

\subsubsection{Hazard Versus Risk}

The term "hazard" as used here relates to potential health effects associated with a contaminant or waste material, assuming that it is already released to the environment. In contrast, the estimates of risk typically used to assess the need for or effectiveness of environmental restoration or waste management activities assume potential health effects and likelihood of contaminant release and subsequent exposure. In simple terms, hazard and risk are related as follows:

Risk $=\begin{aligned} & \text { Probability of } \\ & \text { Release or } \\ & \text { Exposure }\end{aligned}$ X Hazard

Therefore, the term "hazard" as used here relates only to the intrinsic danger to health that would be posed by the contaminant or waste material in the environment in its current physical form and location. Changes in physical form or location of a contaminant or waste that alter its hazard can also change its associated risk. However, it is not necessarily true that that a contaminant or waste with a relatively high hazard poses a high risk in the sense that is usually discussed in "risk assessments."

This relationship between risk and hazard can be used to facilitate calculating HCs. If the risks are compared for a contaminant or waste in differing physical conditions or locations but having the same probability of release or exposure, the relative hazards are related in the same proportion as the relative risks.

Therefore, standard risk-estimating techniques that make the probability of release or exposure constant allow direct estimation of the change in hazard associated with management or restoration actions. The simplest way to "fix" the probability of release or exposure is to assume that the contaminant or waste has already been released. This is the approach that was used to estimate the changes in hazard (i.e., HCs) discussed in the following sections. 


\subsubsection{Factors Affecting the $\mathrm{HC}$}

Five aspects of a contaminant or waste that have significant impacts relative to assessing its hazard are described in the following sections.

\subsubsection{Toxicity or Radiological Nature}

A contaminant's toxic or radiological characteristics determine the severity of its health effects when exposure occurs. Differences among contaminants in this regard are accounted for in the health effects data used in risk assessment methodologies. While typical waste management or environmental restoration activities may affect the amount of contaminant present, they generally do not affect its toxic or radiological nature. Therefore, this aspect of potential hazard is not addressed in assessing HCs for such actions. However, since this factor affects hazard but not HCs, this aspect of hazard is addressed by the $\mathrm{HM}$ factor in the relative hazard calculation.

\subsubsection{Chemical Nature}

The second key aspect of a contaminant affecting its hazard, or the impact of hazard control measures on it, is its chemical nature. Organic and inorganic contaminants generally behave differently both in their environmental transport and their response to treatment. In addition, the hazard associated with a radioactive elements changes spontaneously as it decays.

\subsubsection{Mobility}

A third aspect of a contaminant or waste affecting its hazard is its mobility in the environment. Contaminants that move more readily through the environment are more likely to be transported to off-site receptors than those that are relatively immobile. Thereby, they pose greater health risks to those receptors. In addition, slow transport of radioactive elements allows time for these contaminants to decay prior to exposing receptors.

\subsubsection{Physical Form}

The physical form of a contaminant or waste has a significant impact on its hazard. The physical form of a contaminant or waste affects its availability for transport (i.e., the rate at which it is released). For example, liquid wastes are generally easier to transport than solid wastes and, therefore, are more hazardous. In addition, solid waste that has been treated to immobilize contaminants (e.g., cemented or vitrified) allows contaminants to be released more slowly for transport and, therefore, is less hazardous.

\subsubsection{Location}

A contaminant released to the environment in an isolated location with long transport pathways to receptors is intrinsically less hazardous than the same contaminant in a location that allows rapid transport to receptors. In addition, the hazard reduction associated with a waste management or environmental restoration action will vary depending on the waste's location. 


\subsubsection{Approach for Estimating HCs}

Calculating site-specific HCs for a variety of potential waste management or environmental restoration actions requires taking all these considerations into account. The approach used here is to compare the calculated risks for site-specific conditions before and after such actions are taken to infer the corresponding reduction in hazard, as suggested by the relationship between risk and hazard discussed above.

Such risk calculations can be performed with any risk calculation methodology that allows parametric variation of the key parameters discussed above. For the illustrative calculations discussed below, the Remedial Action Assessment System (RAAS) was utilized (PNNL 1996). RAAS was developed by Pacific Northwest National Laboratory (PNNL) for DOE as an analytical tool for defining and evaluating alternative remedial action strategies for DOE waste sites. The RAAS methodology is useful for this sort of analysis because it allows direct variation of the key waste form and waste location parameters described above.

The RAAS includes elements of the MEPAS for calculating risk for the maximum exposed individual (MEI) as a result of transport of contaminants to potential receptors (Droppo et al. 1989). Comparison of these MEI risks as key waste forms or location factors are varied allows calculation of the corresponding HC.

\subsubsection{Waste Form Variations}

Four different waste forms were analyzed in the following illustrations: liquid waste, soil waste, cemented or grouted waste, and vitrified waste. These classifications represent the most likely forms that will be encountered in assessing hazard reduction measures, and many of the key hazard reduction measures result in a transition from one of these physical states to another.

The relative hazards associated with these states were calculated by comparing the risk associated with equivalent amounts of contaminant already released to the environment. For the solid waste forms (soil waste, cemented or grout wastes, and vitrified waste), in situ wastes of the corresponding waste forms or states were modeled and the corresponding risk calculated. Since these waste were already released, the probability of release or exposure in the risk calculation is the same (i.e., probability of release or exposure is 1.0). Therefore, the relative risks also represent the relative hazards. The liquid waste state was modeled as a pond containing the same amount of contaminant as the soil site. Again, the contaminant is modeled as already released, so the corresponding calculated risk can be used to assess changes in hazard. These calculations, performed for each site of interest, result in the following factors that are subsequently used in $\mathrm{HC}$ calculations:

$$
\begin{aligned}
& \mathrm{GF}=\frac{\text { risk associated with unit of contaminant in cemented/grouted waste }}{\text { risk associated with unit of contaminant in soil waste }} \\
& \mathrm{VF}=\frac{\text { risk associated with unit of contaminant in vitrified waste }}{\text { risk associated with unit of contaminant in soil waste }}
\end{aligned}
$$




$$
\mathrm{SF}=\frac{\text { risk associated with unit of contaminant in liquid waste }}{\text { risk associated with unit of contaminant in soil waste }}
$$

\subsubsection{Hazard Reduction Measures}

Hazard controls were estimated for a variety of waste treatment or environmental restoration activities involving the waste form changes described above. In addition, the following similar factors were defined or estimated (also using the RAAS methodology) for other actions typically occurring as part of waste treatment and environmental restoration:

$$
\begin{aligned}
& \text { FMR }=\text { Fraction of Medium Removed (in contaminated medium) } \\
& \text { FCR }=\text { Fraction Contaminant Remaining (after separation/destruction treatment) } \\
& \mathrm{CF}=\frac{\text { risk associated with unit of contaminant in capped site }}{\text { risk associated with unit of contaminant in soil waste site }} \\
& \mathrm{RF}=\frac{\text { risk associated with unit of contaminant in alternative waste site }}{\text { risk associated with unit of contaminant in original soil waste }}
\end{aligned}
$$

The first two of these (FMR and FCR) relate to actions that change the inventory or contaminant. In general, the hazard associated with a contaminant is proportional to its inventory. If waste is removed from a contaminated site for treatment, the fraction remaining (1 - FMR) retains its initial hazard level, while the fraction removed (FMR) may have a different hazard level, depending on how it is treated and subsequently disposed. Note that this formulation assumes that the contaminant removed is proportional to the medium removed. If this is not the case, then the fraction of the contaminant remaining should be used rather than the fraction of the medium remaining. Similarly, FCR is used to assess the change in hazard associated with in situ or ex situ treatment that separates or destroys the contaminant, thereby changing the contaminant inventory and corresponding hazard. These two factors (i.e., FMR and FCR) are provided to allow the user to make adjustments for inventory reductions within the HC factor; however, these inventory adjustments can also be made by directly adjusting the respective $Q$ values of the RH equation. It is left to the user's discretion to decide where best to account for inventory changes associated with specific risk/hazard management actions, but care should be taken not to "double count" the inventory reductions. Table 2.9 defines the HCs for a variety of potential waste management or environmental restoration actions, in terms of the various hazard reduction factors previously defined.

\subsubsection{Contaminant Categories}

Ideally, the various factors defined above could be calculated for every contaminant of concern and then used as appropriate to estimate HCs for waste management or environmental restoration actions of interest. The RAAS methodology contains the necessary physical, chemical, and health effect data for 
Table 2.9. Hazard Reduction Measures with Generic Hazard Control (HC) Factors

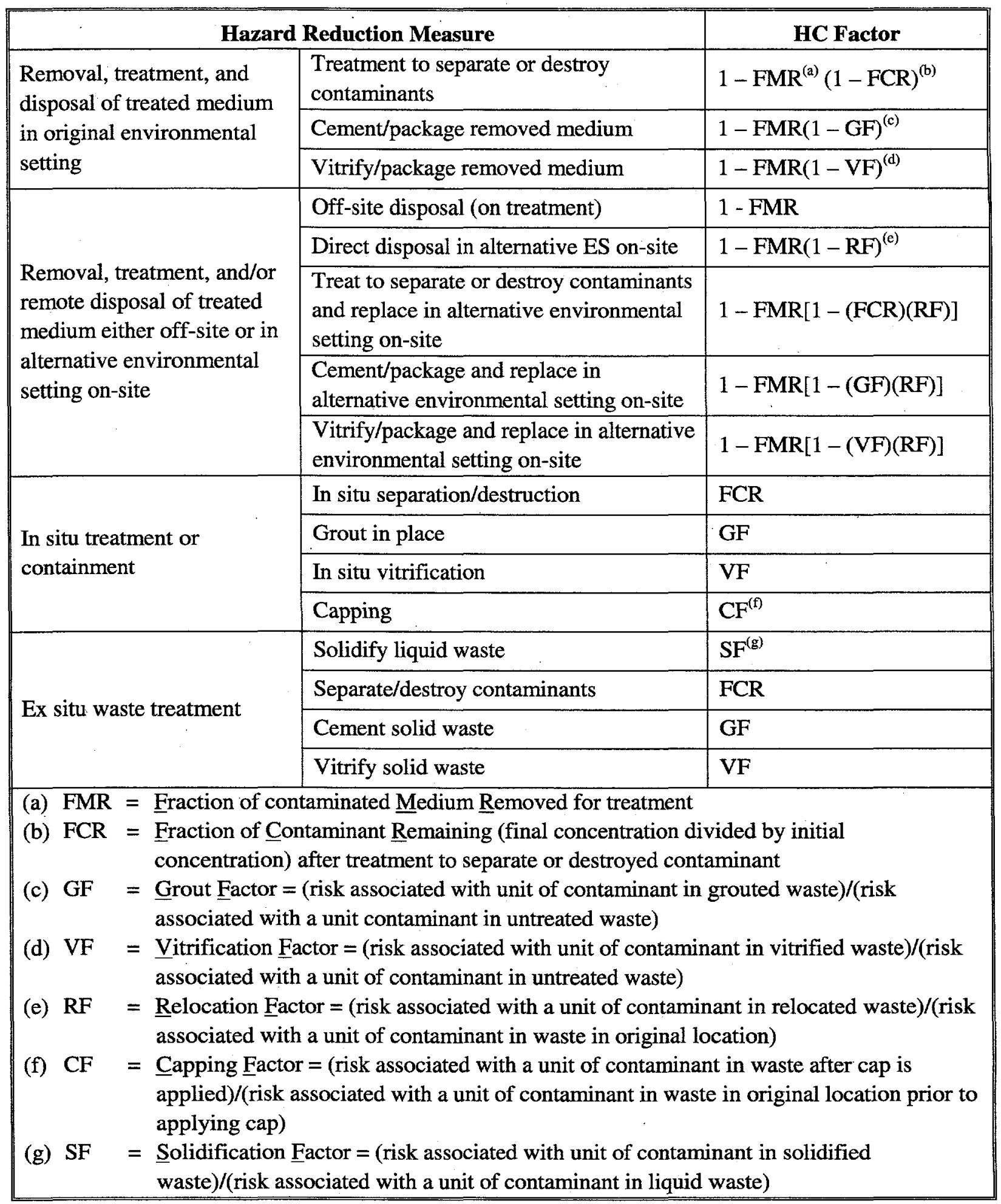


over 400 organic, inorganic, and radioactive contaminants of potential concern. However, performing such comprehensive calculations is time-consuming and probably not warranted in terms of the incremental insight provided. Rather, representative contaminants can be selected and used as surrogates for specific contaminants. As discussed previously, the key contaminant-specific differences of concern relate to the chemical or radiological nature of the contaminant and its mobility.

For the purposes of the illustrative HC estimates developed here, a set of contaminant categories were developed that represent potential variation in these key contaminant characteristics, and a representative contaminant was selected for each category. These categories and representative contaminants are shown in Table 2.10 .

Table 2.10. Contaminant Categories

\begin{tabular}{|c|c|c|c|c|c|c|}
\hline & \multicolumn{3}{|c|}{ Low Mobility } & \multicolumn{3}{c|}{ High Mobility } \\
\cline { 2 - 6 } & & $\begin{array}{c}\text { Inorganic } \\
\text { or Long } \\
\text { Half-Life } \\
\begin{array}{c}\text { Contaminant } \\
\text { Type }\end{array}\end{array}$ & $\begin{array}{c}\text { Short } \\
\text { Half-Life } \\
\text { Radionuclide }\end{array}$ & Organic & $\begin{array}{c}\text { Inorganic } \\
\text { or Long } \\
\text { Half-Life } \\
\text { Radionuclide }\end{array}$ & $\begin{array}{c}\text { Short } \\
\text { Half-Life } \\
\text { Radionuclide }\end{array}$ \\
\hline $\begin{array}{c}\text { Representative } \\
\text { contaminant(s) }\end{array}$ & PCB & $\begin{array}{c}\text { Mercury } \\
{ }^{239} \mathrm{Pu}\end{array}$ & ${ }^{137} \mathrm{Cs}$ & $\mathrm{TCE}$ & $\begin{array}{c}\text { Arsenic } \\
99\end{array}$ & ${ }^{3} \mathrm{Tc}$ \\
\hline
\end{tabular}

\subsubsection{Illustrative Hazard Control Calculations}

The methodology described above was used to develop illustrative HCs for DOE sites, using sitespecific information and data.

Site-Specific Data and Information. Illustrative hazard reduction factors, for use in calculating $\mathrm{HCs}$, were calculated for the following DOE installations and corresponding environmental settings:

DOE Installation

Hanford

INEEL

\section{Environmental Settings}

100-N Area

300 Area

200-E Area

ANL-W

CFA

Playas

TAN

RCWM 
DOE Installation

$\begin{array}{ll} & \text { Coll_WmF } \\ & \text { Coll_WIF } \\ \text { Rocky Flats } & \text { RFA_WmF } \\ & \text { RFA_WIF } \\ & \text { OU3 } \\ & \\ & \text { GS-TNX-D } \\ & \text { KC } \\ \text { Savannah River Plant } & \text { L } \\ & \text { P-R } \\ & \text { A-M }\end{array}$

Multiple "environmental settings" were analyzed for each DOE installation to reflect differences in major site characteristics (stratigraphy, hydrogeology, etc.) that potentially affect the transport of contaminants to receptors and, thus, the risk calculations. These environmental settings are representative of the major areas of interest at these DOE installations. Environmental settings and the corresponding data of interest were developed for analysis supporting DOE's Programmatic Environmental Impact Statement for Waste Management and the Baseline Environmental Management Report (Holdren et al. 1995).

These and supplementary data were used to perform a set of RAAS analyses for each environmental setting (Buck et al. 1997). A "typical" waste site of 10 meters by 10 meters extending the entire depth of the top vadose zone layer was defined. Contaminant concentrations for all eight of the illustrative contaminants previously discussed were set at approximately $1 \%$ of the limiting concentration for each contaminant. Characteristics of the soil, such as porosity and moisture content, and characteristics of the contaminant, such as its distribution coefficient $\left(\mathrm{K}_{\mathrm{d}}\right)$ and solubility, limit the amount of contaminant that can be distributed uniformly in soil without accumulation of pure contamination. The risk for a nearby receptor from a contaminant transported via the groundwater pathway was then calculated by the RAAS methodology. The RAAS methodology reports either the estimated risk (e.g., $10^{-5}$ probability of incremental cancer incidence due to exposure to the contaminant from the waste site) or a lower limit of $10^{-10}$ if a lower magnitude than that is calculated.

Similar risk calculations were performed assuming that the same waste site was capped, grouted in place, or vitrified in place. A fairly high-performance cap was assumed, limiting infiltration to $1 \%$ of normal for 140 years. Using default parameters in the RAAS methodology, typical grout diffusion coefficients and glass leach rates were used to represent grout-in-place and vitrify-in-place scenarios.

For each environmental setting, a contaminated pond or impoundment was also defined containing the same amount of each contaminant as the corresponding soil waste site. The risk for a nearby receptor for contaminant transported from the pond via the groundwater pathway was then calculated by the RAAS methodology. 
Site-Specific Results. Completing the calculations described above for all environmental settings at an installation allowed calculation of all the hazard reduction factors of interest, using the relationships previously described among various risk calculation results.

Tables 2.11 through 2.14 show the results of these calculations for each environmental setting at each DOE installation. These tables do not contain estimates for the FMR and FCR factors. For the purpose of estimating HCs, either ( 1 - FMR) or FCR can be roughly assumed to be in the range of $10^{-3}$ to $10^{-5}$, depending on the particular removal or treatment technology employed.

Also note that the results are shown only as "order of magnitude." The uncertainty implicit in risk estimation calculations makes reporting of additional significant figures misleading.

Table 2.11. Hanford Hazard Control Factor Parameters

\begin{tabular}{|c|c|c|c|c|c|c|c|}
\hline \multirow{4}{*}{$\begin{array}{c}\text { Environ- } \\
\text { mental } \\
\text { Setting } \\
\end{array}$} & \multirow{4}{*}{$\begin{array}{c}\text { Hazard } \\
\text { Reduction } \\
\text { Factor } \\
\end{array}$} & \multicolumn{6}{|c|}{ Contaminant Type } \\
\hline & & \multicolumn{3}{|c|}{ Low Mobility } & \multicolumn{3}{|c|}{ High Mobility } \\
\hline & & Organic & $\begin{array}{c}\text { Inorganic } \\
\text { or Long } \\
\text { Half-Life } \\
\text { Radionuclide } \\
\end{array}$ & $\begin{array}{c}\text { Short } \\
\text { Half-Life } \\
\text { Radionuclide }\end{array}$ & Organic & $\begin{array}{c}\text { Inorganic } \\
\text { or Long } \\
\text { Half-Life } \\
\text { Radionuclide }\end{array}$ & $\begin{array}{c}\text { Short } \\
\text { Half-Life } \\
\text { Radionuclide }\end{array}$ \\
\hline & & PCB & $\begin{array}{c}\text { Mercury } \\
{ }^{239} \mathbf{P u}\end{array}$ & ${ }^{137} \mathrm{Cs}$ & TCE & $\begin{array}{c}\text { Arsenic } \\
{ }^{99} \mathbf{T c} \\
\end{array}$ & ${ }^{3} \mathbf{H}$ \\
\hline \multirow{5}{*}{$\begin{array}{l}100-\mathrm{N} \\
\text { Area }\end{array}$} & GF & 1 & 1 & 1. & 1 & 1 & $10^{-1}$ \\
\hline & VF & $<10^{-10}$ & 1 & $10^{-2}$ & $<10^{-10}$ & $10^{-3}$ & $10^{-5}$ \\
\hline & RF & 1 & 1 & $<10^{-10}$ & $10^{-1}$ & $<10^{-10}$ & $<10^{-10}$ \\
\hline & $\mathrm{CF}$ & 1 & 1 & 1 & 1 & 1 & $10^{-2}$ \\
\hline & SF & $10^{-5}$ & $10^{-1}$ & $<10^{-10}$ & 1 & 1 & 1 \\
\hline \multirow{5}{*}{300 Area } & GF & 1 & 1 & 1 & 1 & 1 & $10^{-1}$ \\
\hline & VF & $<10^{-10}$ & $10^{-1}$ & $10^{-3}$ & $<10^{-10}$ & $10^{-3}$ & $10^{-5}$ \\
\hline & RF & $10^{-2}$ & $10^{-8}$ & $<10^{-10}$ & 1 & $10^{-8}$ & $<10^{-10}$ \\
\hline & $\mathrm{CF}$ & 1 & 1 & 1 & 1 & 1 & $10^{-2}$ \\
\hline & SF & $10^{-3}$ & $10^{-1}$ & $.10^{-3}$ & 1 & $10^{-1}$ & 1 \\
\hline \multirow{5}{*}{$\begin{array}{l}200-\mathrm{E} \\
\text { Area }\end{array}$} & GF & 1 & 1 & 1 & 1 & 1 & 1 \\
\hline & VF & 1 & 1 & 1 & 1 & 1 & 1 \\
\hline & RF & \multicolumn{6}{|c|}{ Environmental Setting Assumed for Alternative On-Site Disposal Site, RF $=1.0$} \\
\hline & $\mathrm{CF}$ & 1 & 1 & 1 & 1 & 1 & 1 \\
\hline & SF & $10^{-5}$ & $<10^{-10}$ & $<10^{-10}$ & 1 & $10^{-8}$ & $<10^{-10}$ \\
\hline
\end{tabular}


Table 2.12. INEEL Hazard Control Factor Parameters

\begin{tabular}{|c|c|c|c|c|c|c|c|}
\hline \multirow{4}{*}{$\begin{array}{c}\text { Environ- } \\
\text { mental } \\
\text { Setting } \\
\end{array}$} & \multirow{4}{*}{$\begin{array}{c}\text { Hazard } \\
\text { Reduction } \\
\text { Factor } \\
\end{array}$} & \multicolumn{6}{|c|}{ Contaminant Type } \\
\hline & & \multicolumn{3}{|c|}{ Low Mobility } & \multicolumn{3}{|c|}{ High Mobility } \\
\hline & & Organic & $\begin{array}{c}\text { Inorganic } \\
\text { or Long } \\
\text { Half-Life } \\
\text { Radionuclide } \\
\end{array}$ & $\begin{array}{c}\text { Short } \\
\text { Half-Life } \\
\text { Radionuclide } \\
\end{array}$ & Organic & $\begin{array}{c}\text { Inorganic } \\
\text { or Long } \\
\text { Half-Life } \\
\text { Radionuclide } \\
\end{array}$ & $\begin{array}{c}\text { Short } \\
\text { Half-Life } \\
\text { Radionuclide }\end{array}$ \\
\hline & & PCB & $\begin{array}{c}\text { Mercury } \\
{ }^{239} \mathbf{P u}\end{array}$ & ${ }^{137} \mathrm{Cs}$ & TCE & $\begin{array}{c}\text { Arsenic } \\
{ }^{99} \mathrm{Tc}\end{array}$ & ${ }^{3} \mathbf{H}$ \\
\hline \multirow{5}{*}{ ANL-W } & GF & 1 & 1 & 1 & 1 & 1 & 1 \\
\hline & VF & $<10^{-10}$ & 1 & 1 & $<10^{-10}$ & 1 & 1 \\
\hline & RF & 1 & 1 & 1 & $10^{-1}$ & 1 & 1 \\
\hline & $\mathrm{CF}$ & 1 & 1 & 1 & 1 & 1 & 1 \\
\hline & SF & $10^{-3}$ & $<10^{-10}$ & $<10^{-10}$ & $10^{-1}$ & $10^{-8}$ & $<10^{-10}$ \\
\hline \multirow{5}{*}{ CFA } & GF & 1 & 1 & 1 & 1 & 1 & 1 \\
\hline & VF & $<10^{-10}$ & 1 & 1 & $<10^{-10}$ & 1 & 1 \\
\hline & RF & 1 & 1 & 1 & $10^{-1}$ & 1 & 1 \\
\hline & $\mathrm{CF}$ & 1 & 1 & 1 & 1 & 1 & 1 \\
\hline & SF & 1 & $<10^{-10}$ & $10^{-6}$ & $10^{-1}$ & $<10^{-10}$ & $<10^{-10}$ \\
\hline \multirow{5}{*}{ Playas } & GF & 1 & 1 & 1 & 1 & 1 & 1 \\
\hline & $\mathrm{VF}$ & $<10^{-10}$ & 1 & 1 & $<10^{-10}$ & 1 & 1 \\
\hline & RF & 1 & 1 & 1 & $10^{-1}$ & 1 & $10^{-1}$ \\
\hline & $\mathrm{CF}$ & 1 & 1 & 1 & 1 & 1 & 1 \\
\hline & SF & 1 & 1 & 1 & $10^{-2}$ & $10^{-8}$ & $10^{-9}$ \\
\hline \multirow{5}{*}{ TAN } & GF & 1 & 1 & 1 & 1 & 1 & 1 \\
\hline & VF & $<10^{-10}$ & 1 & 1 & $<10^{-10}$ & 1 & 1 \\
\hline & RF & 1 & 1 & 1 & $10^{-1}$ & 1 & $10^{-1}$ \\
\hline & $\mathrm{CF}$ & 1 & 1 & 1 & 1 & 1 & 1 \\
\hline & SF & 1 & 1 & 1 & $10^{-2}$ & $10^{-8}$ & $<10^{-10}$ \\
\hline \multirow{5}{*}{ RCWM } & GF & 1 & 1 & 1 & 1 & 1 & 1 \\
\hline & VF & 1 & 1 & 1 & 1 & 1 & 1 \\
\hline & RF & \multicolumn{6}{|c|}{ Environmental Setting Assumed for Alternative On-Site Disposal Site, $R F=1.0$} \\
\hline & $\mathrm{CF}$ & 1 & 1 & 1 & 1 & 1 & 1 \\
\hline & SF & 1 & 1 & 1 & 1 & 1 & 1 \\
\hline
\end{tabular}


Table 2.13. Rocky Flats Hazard Control Factor Parameters

\begin{tabular}{|c|c|c|c|c|c|c|c|}
\hline \multirow{4}{*}{$\begin{array}{c}\text { Environ- } \\
\text { mental } \\
\text { Setting }\end{array}$} & \multirow{4}{*}{$\begin{array}{c}\text { Hazard } \\
\text { Reduction } \\
\text { Factor } \\
\end{array}$} & \multicolumn{6}{|c|}{ Contaminant Type } \\
\hline & & \multicolumn{3}{|c|}{ Low Mobility } & \multicolumn{3}{|c|}{ High Mobility } \\
\hline & & Organic & $\begin{array}{c}\text { Inorganic } \\
\text { or Long } \\
\text { Half-Life } \\
\text { Radionuclide } \\
\end{array}$ & $\begin{array}{c}\text { Short } \\
\text { Half-Life } \\
\text { Radionuclide }\end{array}$ & Organic & $\begin{array}{c}\text { Inorganic or } \\
\text { Long } \\
\text { Half-Life } \\
\text { Radionuclide } \\
\end{array}$ & $\begin{array}{c}\text { Short } \\
\text { Half-Life } \\
\text { Radionuclide }\end{array}$ \\
\hline & & PCB & $\begin{array}{c}\text { Mercury } \\
{ }^{239} \mathbf{P u}\end{array}$ & ${ }^{137} \mathrm{Cs}$ & TCE & $\begin{array}{c}\text { Arsenic } \\
{ }^{99} \mathrm{Tc}\end{array}$ & ${ }^{3} \mathbf{H}$ \\
\hline \multirow{5}{*}{ Coll_WmF } & GF & 1 & 1 & 1 & 1 & 1 & 1 \\
\hline & $\mathrm{VF}$ & $<10^{-10}$ & 1 & $10^{-1}$ & $<10^{-10}$ & $10^{-2}$ & $10^{4}$ \\
\hline & $\mathrm{RF}$ & $10^{-1}$ & $10^{-1}$ & $10^{-1}$ & $10^{-1}$ & $10^{-1}$ & $10^{-1}$ \\
\hline & $\mathrm{CF}$ & 1 & 1 & $10^{-1}$ & 1 & 1 & $10^{-2}$ \\
\hline & SF & $10^{-1}$ & $10^{-1}$ & $10^{-1}$ & 1 & 1 & 1 \\
\hline \multirow{5}{*}{ Coll_WIF } & GF & 1 & 1 & 1 & 1 & 1 & 1 \\
\hline & $\mathrm{VF}$ & $<10^{-10}$ & 1 & $10^{-1}$ & $<10^{-10}$ & $10^{-2}$ & $10^{-4}$ \\
\hline & RF & $10^{-1}$ & $10^{-1}$ & $10^{-1}$ & $10^{-1}$ & $10^{-1}$ & $10^{-1}$ \\
\hline & $\mathrm{CF}$ & 1 & 1 & $10^{-1}$ & 1 & 1 & $10^{-2}$ \\
\hline & SF & $10^{-1}$ & $10^{-1}$ & $10^{-1}$ & 1 & 1 & 1 \\
\hline \multirow{5}{*}{ RFA_WmF } & GF & 1 & 1 & 1 & 1 & 1 & 1 \\
\hline & VF & $<10^{-10}$ & $10^{-1}$ & 1 & $<10^{-10}$ & $10^{-2}$ & $10^{-4}$ \\
\hline & RF & 1 & 1 & $10^{-1}$ & $10^{-1}$ & $10^{-1}$ & $10^{-1}$ \\
\hline & $\mathrm{CF}$ & 1 & 1 & $10^{-1}$ & 1 & 1 & $10^{-1}$ \\
\hline & SF & 1 & 1 & 1 & 1 & 1 & 1 \\
\hline \multirow{5}{*}{ RFA_WIF } & GF & $\cdot 1$ & 1 & 1 & 1 & 1 & 1 \\
\hline & VF & $<10^{-10}$ & $10^{-1}$ & 1 & $<10^{-10}$ & $10^{-2}$ & $10^{-4}$ \\
\hline & RF & 1 & 1 & $10^{-1}$ & $10^{-1}$ & $10^{-1}$ & $10^{-1}$ \\
\hline & $\mathrm{CF}$ & 1 & 1 & $10^{-1}$ & 1 & 1 & $10^{-1}$ \\
\hline & SF & 1 & 1 & 1 & 1 & 1 & 1 \\
\hline \multirow{5}{*}{ OU3 } & GF & 1 & 1 & 1 & 1 & 1 & 1 \\
\hline & VF & $<10^{-10}$ & $10^{-1}$ & 1 & $<10^{-10}$ & $10^{-2}$ & $10^{-4}$ \\
\hline & RF & \multicolumn{6}{|c|}{ Environmental Setting Assumed for Alternative On-Site Disposal Site, RF = 1.0} \\
\hline & $\mathrm{CF}$ & 1 & 1 & $10^{-1}$ & 1 & 1 & $10^{-1}$ \\
\hline & SF & $10^{-2}$ & $10^{-2}$ & $10^{-1}$ & 1 & $10^{-2}$ & $10^{-1}$ \\
\hline
\end{tabular}


Table 2.14. Savannah River Hazard Control Factor Parameters

\begin{tabular}{|c|c|c|c|c|c|c|c|}
\hline \multirow{4}{*}{$\begin{array}{c}\text { Environ- } \\
\text { mental } \\
\text { Setting } \\
\end{array}$} & \multirow{4}{*}{$\begin{array}{c}\text { Hazard } \\
\text { Reduction } \\
\text { Factor } \\
\end{array}$} & \multicolumn{6}{|c|}{ Contaminant Type } \\
\hline & & \multicolumn{3}{|c|}{ Low Mobility } & \multicolumn{3}{|c|}{ High Mobility } \\
\hline & & Organic & $\begin{array}{c}\text { Inorganic } \\
\text { or Long } \\
\text { Half-Life } \\
\text { Radionuclide }\end{array}$ & $\begin{array}{c}\text { Short } \\
\text { Half-Life } \\
\text { Radionuclide }\end{array}$ & Organic & $\begin{array}{c}\text { Inorganic } \\
\text { or Long } \\
\text { Half-Life } \\
\text { Radionuclide }\end{array}$ & $\begin{array}{c}\text { Short } \\
\text { Half-Life } \\
\text { Radionuclide }\end{array}$ \\
\hline & & PCB & $\begin{array}{c}\text { Mercury } \\
{ }^{239} \mathbf{P u}\end{array}$ & ${ }^{137} \mathrm{Cs}$ & TCE & \begin{tabular}{|c|}
$\begin{array}{c}\text { Arsenic } \\
{ }^{99} \mathrm{Tc}\end{array}$ \\
\end{tabular} & ${ }^{3} \mathbf{H}$ \\
\hline \multirow{5}{*}{ GS-TNX-D } & GF & 1 & 1 & 1 & 1 & 1 & $10^{-1}$ \\
\hline & VF & $<10^{-10}$ & $10^{-2}$ & $10^{-2}$ & $<10^{-10}$ & $10^{-4}$ & $10^{-6}$ \\
\hline & $\mathrm{RF}$ & 1 & $10^{-2}$ & $10^{-2}$ & $10^{-2}$ & $10^{-2}$ & $10^{-2}$ \\
\hline & $\mathrm{CF}$ & 1 & 1 & 1 & 1 & 1 & $10^{-2}$ \\
\hline & SF & 1 & 1 & 1 & 1 & 1 & 1 \\
\hline \multirow{5}{*}{$\mathrm{KC}$} & GF & 1 & 1 & 1 & 1 & 1 & $10^{-1}$ \\
\hline & VF & $<10^{-10}$ & $10^{-2}$ & $10^{-3}$ & $<10^{-10}$ & $10^{-4}$ & $10^{-6}$ \\
\hline & RF & 1 & $10^{-1}$ & $10^{-2}$ & $10^{-2}$ & $10^{-2}$ & $10^{-2}$ \\
\hline & $\mathrm{CF}$ & 1 & 1 & 1 & 1 & 1 & $10^{-2}$ \\
\hline & SF & 1 & 1 & 1 & 1 & 1 & 1 \\
\hline \multirow{5}{*}{$\mathrm{L}$} & GF & 1 & 1 & 1 & 1 & 1 & $10^{-1}$ \\
\hline & VF & $<10^{-10}$ & $10^{-2}$ & $10^{-3}$ & $<10^{-10}$ & $10^{-4}$ & $10^{-6}$ \\
\hline & RF & 1 & $10^{-1}$ & $10^{-2}$ & $10^{-2}$ & $10^{-2}$ & $10^{-2}$ \\
\hline & $\mathrm{CF}$ & 1 & 1 & 1 & 1 & 1 & $10^{-2}$ \\
\hline & SF & 1 & 1 & 1 & 1 & 1 & 1 \\
\hline \multirow{5}{*}{ P-R } & GF & 1 & 1 & 1 & 1 & 1 & $10^{-1}$ \\
\hline & VF & $<10^{-10}$ & $10^{-2}$ & $10^{-3}$ & $<10^{-10}$ & $10^{-4}$ & $10^{-6}$ \\
\hline & RF & 1 & $10^{-2}$ & $10^{-2}$ & $10^{-2}$ & $10^{-2}$ & $10^{-2}$ \\
\hline & $\mathrm{CF}$ & 1 & 1 & 1 & 1 & 1 & $10^{-2}$ \\
\hline & $\mathrm{SF}$ & 1 & 1 & 1 & 1 & 1 & 1 \\
\hline \multirow{5}{*}{ A-M } & GF & 1 & 1 & 1 & 1 & 1 & $10^{-1}$ \\
\hline & VF & $<10^{-10}$ & $10^{-1}$ & 1 & $<10^{-10}$ & $10^{-2}$ & $10^{-4}$ \\
\hline & RF & \multicolumn{6}{|c|}{ Environmental Setting Assumed for Alternative On-Site Disposal Site, RF = 1.0} \\
\hline & $\mathrm{CF}$ & 1 & 1 & 1 & 1 & 1 & $10^{-2}$ \\
\hline & SF & $10^{-2}$ & $10^{-2}$ & $10^{-2}$ & 1 & $10^{-5}$ & $10^{-1}$ \\
\hline
\end{tabular}




\subsection{Approach to Calculating Relative Hazard Ratios Using the Relative Hazard Equation}

In using the RH equation to estimate $\mathrm{RH}$ ratios and produce relative hazard reduction graphs, one should always apply the test of "technical feasibility and reasonableness" to each factor of the equation and to the final resulting $\mathrm{RH}$ value generated over the course of the projected risk management actions. In most cases, it will be helpful to sketch out an intuitive RH graph considering all the risk management actions being considered. Then, once the RH calculations are made, a comparison of the resulting graph with the intuitive graph can be made to test the reasonableness of the results. Any significant discrepancies should be examined by looking at the individual parameters and the logic behind them.

The general steps of the RH estimation methodology include the following:

- Use the site-specific "Current Risk/Hazards" and "Future Risk/Hazard Management Actions" tables of the site's risk profile to determine the controlling constituents, quantities (considering total amounts and releasable fractions of controlling constituents), controlling pathways, and risk management actions pertinent to the waste type being evaluated.

- Assign site-specific values for the base case and each risk/hazard management action case to the parameters of the $\mathrm{RH}$ equation, using data from the risk profile tables, site-specific risk assessment data, values from look-up tables, and general knowledge of the site in question.

- Assign quantity (Q) and release fraction (RF) values for the controlling constituents. If values of $\mathrm{Q}$ are all releasable to the controlling pathway, the respective $\mathrm{RF}$ value can be assigned a 1 .

- Assign hazard measure (HM) values (specific for the controlling constituent and pathway), using the HM look-up tables provided. As the overall risk management approach is examined, consider the logic flow where a specific risk/hazard management activity may cause a change from one pathway to another or a change in the status of the controlling constituent. For instance, there may be a separations and disposal process where the initial controlling constituent is either changed or eliminated resulting in a different controlling constituent.

- Assign hazard control (HC) values (specific for each risk/hazard management activity). In many cases, the $\mathrm{HC}$ is simply related to the reduction in the volume (i.e., amount of controlling constituents) of the hazardous material in question. In these cases, simply assign the $\mathrm{HC}$ a value of 1 and adjust the $Q$ values over time to reflect the reduction, or use the FMR and/or FCR factors, as applicable, to generate an $\mathrm{HC}$ value to account for the volume change. The $\mathrm{HC}$ values are intended to reflect significant impact changes in the waste material or its setting, e.g., vitrification of the same amount of waste to change its form, repackaging leaking hazardous material or moving hazardous material away from a vulnerable exposure setting. In some cases, there will be both reduction in volume and changes in the waste material or setting. A representative $\mathrm{HC}$ value should then be used, along with a reduction in the $Q$ values (or the appropriate FMR and/or FCR factors of the $\mathrm{HC}$ used to account for the volume change). If risk assessment results are available 
for the general activity or a related activity at the site, use the results of the risk assessment to estimate the order of magnitude of the activity. If no pertinent risk assessment results are available, use the $\mathrm{HC}$ look-up tables provided to estimate the worth of the activity. Use these table values in combinations with the Q and HM parameters to as closely as possible represent the logic flow of all the risk management activities at the site.

- Assemble all of the RH equation factor values, with references and assumption information documented, into a simple worksheet format to provide documentation for the analysis process.

- Calculate the RH ratio values, considering the general flow of activities that occur over time. As mentioned, it would be helpful to sketch out an intuitive graph of the activities over time. These sketches will prove invaluable in selecting the best RH equation input factors and increase the likelihood that the results are logically reasonable.

- Assign "best estimate" relative time (RT) values based on the general understanding of time associated with the completion of each risk/hazard management activity. In many cases, quantity and activity data are presented on a year-by-year basis, which is the best data for an RH graph. In these cases, simply assign RT values by year. In cases, where these year-by-year data are not available, it will be necessary to estimate the number of years out from the starting time that each risk/hazard management activity is projected to occur and the amount of time that it will take to complete the activity. Then, assign these time blocks to the respective RT values.

- Develop a plotting table, using the plotting routine software of your choice, and produce the individual waste type RH versus RT plots. For purposes of the risk profiles, use only order-of-magnitude axes scaling (listing of axis values is optional), label the axes, and write the pertinent risk/hazard management action identifier information directly on the graphs. In past riskprofile development, several sites have asked not to have the axis values presented because they can easily get misinterpreted as absolute risk values (i.e., order-of-magnitude risk values). This problem was solved by simply including tick marks and noting in the text (and/or as footnotes) that each tick mark represents an order of magnitude reduction in the relative hazard. 


\subsection{Application Examples}

Example RH calculations and graphs are provided in the following sections to illustrate the method's application to actual site examples and its flexibility working with the data-availability constraints and a site's specific risk story. Two example cases, with considerably different levels of available input data, are shown to illustrate flexibility. Close examination of the RH equations, as presented in the examples, shows that the methodology tends to single out the specific risk (hazard) management factors that are being altered by the projected risk management actions. The methodology can adjust as many factors in the RH equation as necessary to best represent the hazard reduction effected by a projected risk management activity.

\subsection{Example Site \#1}

Example Site \#1 provides a good example of a site with known declining (decaying) inventory. Each time increment is 10 years. The site has a large volume of waste containing some relatively short half-life material that will naturally decline over the years. To simplify, the site inventory was divided into either surface or sub-surface inventory categories. The inventory information is presented in Tables 3.1 (SubSurface Inventory) and 3.2 (Surface Inventory). Inventory amounts in the tables are in curies.

\subsubsection{Surface Contamination Calculation Notes}

The GW pathway is assumed to be the controlling pathway.

The total initial inventory associated with surface contamination, as taken from Table 3.2 , is $2042 \mathrm{Ci}$.

$$
Q \text { total }=2042 \mathrm{Ci}
$$

The baseline disposition maps show an $8 \%$ reduction in this inventory associated with treatment and offsite disposal (i.e., $168 \mathrm{Ci}$ ); a $0.9 \%$ reduction due to offsite disposal (i.e., $18 \mathrm{Ci}$ ); and a $0.4 \%$ reduction due to continued onsite controls (i.e., $8 \mathrm{Ci}$ ). The treatment and onsite disposal activities need to consider decay as a means of reducing the inventory of radionuclides. This reduction in inventory is shown in Table 3.2 (i.e., 2042-Ci initial inventory and 1300-Ci decayed inventory for the 70-year period shown).

$$
\begin{array}{lll}
\mathrm{Q} \text { treatment and offsite disposal } & =168 \mathrm{Ci} \\
\mathrm{Q} \text { offsite disposal } & =18 \mathrm{Ci} \\
\mathrm{Q} \text { continued onsite control } & =8 \mathrm{Ci} \text { (part of current operations) } \\
\mathrm{Q} \text { treatment and onsite disposal } & =2042 \mathrm{Ci} ; \mathrm{Q} \text { w/decay over } 70 \mathrm{y}=1300 \mathrm{Ci}
\end{array}
$$

It was assumed that all of the inventory was releasable to the environment. Thus,

$$
\mathrm{RF}=1
$$


Table 3.1. Sub-Surface Inventory

\begin{tabular}{|c|c|c|c|c|c|c|c|c|c|c|c|c|c|c|c|c|}
\hline Rad & $\begin{array}{c}\text { Initial } \\
\text { Inv. }\end{array}$ & $\begin{array}{l}\text { Act. } \\
\text { Frac. }\end{array}$ & $\begin{array}{l}10 \mathrm{y} \\
\text { Inv. }\end{array}$ & $\begin{array}{l}\text { Act. } \\
\text { Frac }\end{array}$ & $\begin{array}{l}20 y \\
\text { Inv. }\end{array}$ & $\begin{array}{l}\text { Act. } \\
\text { Frac }\end{array}$ & $\begin{array}{l}30 \mathrm{y} \\
\text { Inv. }\end{array}$ & $\begin{array}{l}\text { Act. } \\
\text { Frac }\end{array}$ & $\begin{array}{l}40 \mathrm{y} \\
\text { Inv. }\end{array}$ & $\begin{array}{l}\text { Act. } \\
\text { Frac }\end{array}$ & $\begin{array}{l}50 \mathrm{y} \\
\text { Inv. }\end{array}$ & $\begin{array}{l}\text { Act. } \\
\text { Frac }\end{array}$ & $\begin{array}{l}60 y \\
\text { Inv. }\end{array}$ & $\begin{array}{l}\text { Act. } \\
\text { Frac }\end{array}$ & $\begin{array}{l}70 \mathrm{y} \\
\text { Inv. }\end{array}$ & $\begin{array}{l}\text { Act. } \\
\text { Frac }\end{array}$ \\
\hline${ }^{3} \mathrm{H}$ & $1.0 \mathrm{E} 8$ & 0.901 & $5.7 \mathrm{E} 7$ & 0.869 & $3.3 \mathrm{E} 7$ & 0.828 & $1.9 \mathrm{E} 7$ & 0.777 & $1.1 \mathrm{E} 7$ & 0.715 & $6.0 \mathrm{E} 6$ & 0.643 & $3.4 \mathrm{E} 6$ & 0.564 & $2.0 \mathrm{E} 6$ & 0.481 \\
\hline${ }^{85} \mathrm{Kr}$ & $3.7 \mathrm{E} 5$ & 0.003 & $1.9 \mathrm{E} 5$ & 0.003 & $1.0 \mathrm{E} 5$ & 0.003 & $5.3 \mathrm{E} 4$ & 0.002 & $2.8 \mathrm{E} 4$ & 0.002 & $1.5 \mathrm{E} 4$ & 0.002 & $7.6 \mathrm{E} 3$ & 0.001 & $4.0 \mathrm{E} 3$ & 0.001 \\
\hline${ }^{137} \mathrm{Cs}$ & $5.7 \mathrm{E} 6$ & 0.051 & $4.5 \mathrm{E} 6$ & 0.068 & $3.6 \mathrm{E} 6$ & 0.091 & $2.9 \mathrm{E} 6$ & 0.119 & $2.3 \mathrm{E} 6$ & 0.153 & $1.8 \mathrm{E} 6$ & 0.192 & $1.4 \mathrm{E} 6$ & 0.235 & $1.1 \mathrm{E} 6$ & 0.280 \\
\hline${ }^{151} \mathrm{Sm}$ & $1.9 \mathrm{E} 5$ & 0.002 & $1.8 \mathrm{E} 5$ & 0.003 & $1.6 \mathrm{E} 5$ & 0.004 & $1.5 \mathrm{E} 5$ & 0.006 & $1.4 \mathrm{E} 5$ & 0.009 & $1.3 \mathrm{E} 5$ & 0.014 & $1.2 \mathrm{E} 5$ & 0.020 & $1.1 \mathrm{E} 5$ & 0.027 \\
\hline
\end{tabular}

Table 3.2. Surface Inventory

is

\begin{tabular}{|c|c|c|c|c|c|c|c||}
\hline Rad & $\mathbf{T} 1 / 2$ (d) & Initial Inv. (Ci) & Initial \% & $\begin{array}{c}\text { Frac. Of N 25550 } \\
\text { (t,days) }\end{array}$ & 70 y Inv. (Ci) & \% at 70 y & $\begin{array}{c}\text { \% Reduction In } \\
\text { Total }\end{array}$ \\
\hline${ }^{60} \mathrm{Co}$ & $1.92 \mathrm{E} 3$ & 35 & 1.71 & $9.9 \mathrm{E}-5$ & $3.5 \mathrm{E}-3$ & 0.0 & 10 \\
\hline${ }^{90} \mathrm{Sr}$ & $1.04 \mathrm{E} 4$ & 330 & 16.16 & $1.8 \mathrm{E}-1$ & $6.0 \mathrm{E} 1$ & 4.5 & 81.8 \\
\hline${ }^{137} \mathrm{Cs}$ & $1.10 \mathrm{E} 4$ & 310 & 15.18 & $2.0 \mathrm{E}-1$ & $6.2 \mathrm{E} 1$ & 4.7 & 80 \\
\hline${ }^{152} \mathrm{Eu}$ & $4.96 \mathrm{E} 3$ & 147 & 7.20 & $2.8 \mathrm{E}-2$ & 4.1 & 0.3 & 97.2 \\
\hline${ }^{239} \mathrm{Pu}$ & $8.81 \mathrm{E} 6$ & 1070 & 52.40 & 1.0 & $1.1 \mathrm{E} 3$ & 80.4 & 2.8 \\
\hline${ }^{241} \mathrm{Am}$ & $1.58 \mathrm{E} 5$ & 150 & 7.35 & $8.9 \mathrm{E}-1$ & $1.3 \mathrm{E} 2$ & 10.1 & 13.3 \\
\hline Total & & 2042 & 100.00 & & $1.3 \mathrm{E} 3$ & 100.00 & 36.3 \\
\hline
\end{tabular}


The plutonium isotopes were considered to be the controlling constituents for the analysis. Using the HM look-up table for the groundwater pathway, an HM value of 10 was assigned.

$$
\mathrm{HM}=10
$$

An $\mathrm{HC}$ factor of one (1) is assigned to current operations because this is assumed to be the baseline from which to compare the reductions. Based on the disposition maps, the site estimated the fraction of media removed (i.e., FMR) from the amount associated with treatment and offsite hazardous disposal (i.e., the $168 \mathrm{Ci}$ ) is roughly $12 \%$ (i.e., $\mathrm{FMR}=0.12$ ). Based on past experience and assessments, the site estimated that their treatment and onsite disposal operations effected roughly four orders of magnitude reduction in risk. This reduction was assumed to be associated with controlling the hazard; thus, an HC value of E-4 was assigned to the treatment and onsite disposal operations: Thus,

$\begin{array}{ll}\mathrm{HC} \text { current operations } & =1 \\ \mathrm{HC} \text { treatment and offsite hazardous disposal } & =(1-\mathrm{FMR})=(1-0.12)=0.88 \\ \mathrm{HC} \text { treatment and onsite disposal } & =\mathrm{E}-4\end{array}$

Applying the above factors to the RH equation results in the following RH values for the various risk/hazard management actions projected for the site:

RH current operations $=(2042 / 2042)(1 / 1)(10 / 10)(1 / 1)]=1$

$\mathrm{RH}$ treatment and offsite hazardous material disposal $=(168 / 2042)(10 / 10)(0.88 / 1)=0.07$

$\mathrm{RH}$ treatment and onsite disposal without decay $=(2042 / 2042)(10 / 10)(\mathrm{E}-4 / 1)=1.0 \mathrm{E}-4$

$\mathrm{RH}$ treatment and onsite disposal with decay $=(1300 / 2042)(10 / 10)(\mathrm{E}-4 / 1)=6.4 \mathrm{E}-5$

The risk profile tables show that the remediation of offsite surface contamination is scheduled to begin in 2006; thus, an RT period from 0.0 to 7.0 was assigned to current operations. It was estimated that the treatment and offsite hazardous material disposal operations will take roughly three (3) years; thus, an RT value of 10 was assigned to this action. The analysis was performed for a 70 -year period; thus, an RT value was assigned to the treatment and onsite disposal with decay operations. The treatment and onsite disposal without decay RH calculation was provided above simply to examine the effect of the decay. The following plot table was produced, as was Figure 3.1:

\begin{tabular}{rl}
\multicolumn{1}{c}{ RT } & \multicolumn{1}{c}{ RH } \\
\hline 0.00 & 1.00 \\
7.00 & 1.00 \\
10.00 & 0.07 \\
70.00 & $6.40 \mathrm{E}-5$
\end{tabular}




\section{Surface Contamination}

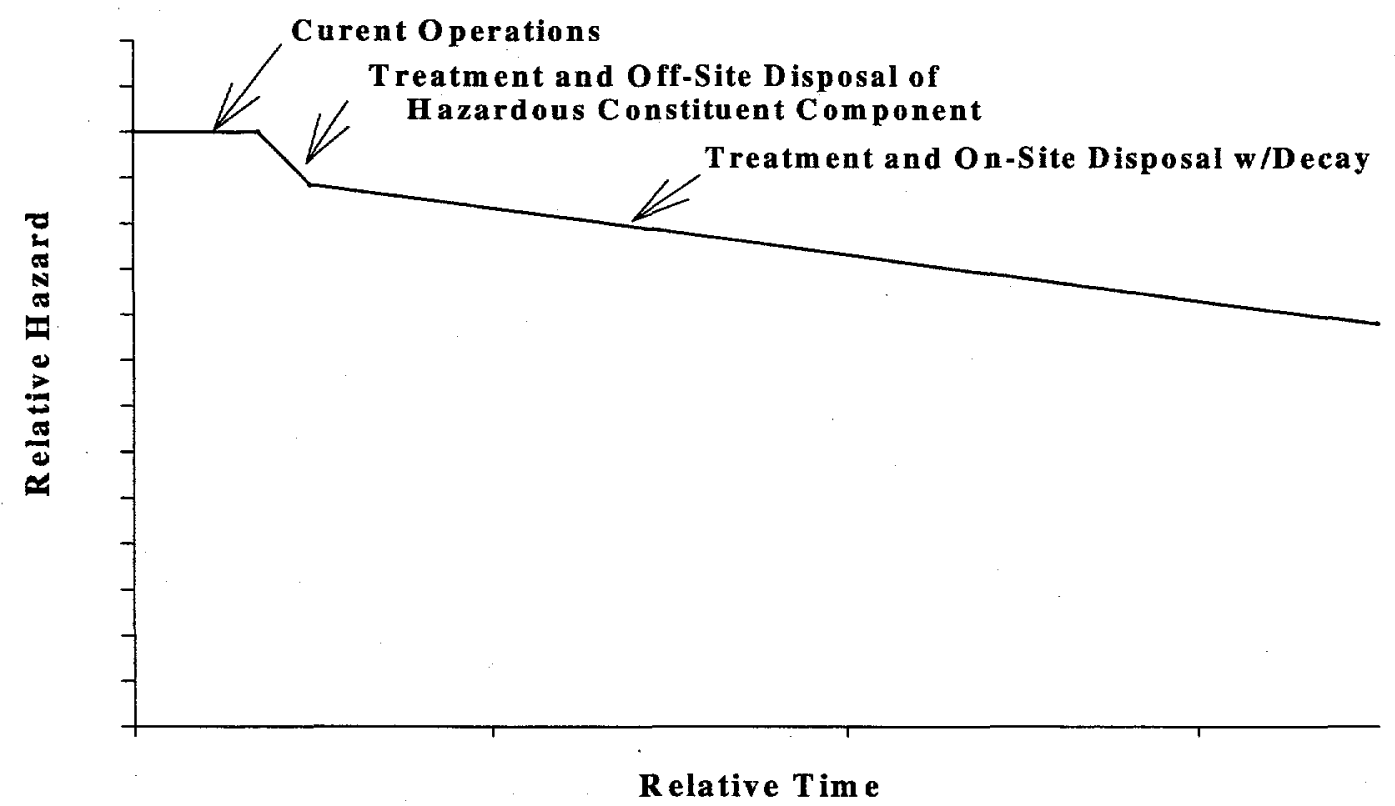

Figure 3.1. Surface Contamination Calculated for Example Site \#1

\subsubsection{Sub-Surface Contamination Calculation Notes}

The GW pathway is assumed to be the controlling pathway.

The total initial inventory associated with sub-surface contamination, as taken from Table 3.1 , is $1.1 \mathrm{E} 8 \mathrm{Ci}$.

$$
\mathrm{Q} \text { subsurface contamination }=1.1 \mathrm{E} 8 \mathrm{Ci}
$$

Based on information provided in Table 3.1, decay results in a 70-year inventory of 4.1E6 Ci.

$$
Q \text { subsurface contamination } w / 70 \mathrm{y} \text { decay }=4.1 \mathrm{E} 6 \mathrm{Ci}
$$

It was assumed that all of the inventory was releasable to the environment.

$$
\mathrm{RF}=1.0
$$

The ${ }^{137} \mathrm{Cs}$ isotope was considered to be the controlling constituent. It had the highest activity fraction, next to tritium, and it also had the highest associated HM factor (1000) from the groundwater table.

$$
\mathrm{HM}=1000
$$


A robust groundwater monitoring and control program is cited in the risk profile table for the risk management action for sub-surface contamination. While such a program is essential to safely maintain the sub-surface contamination, it does not reduce the hazard.

$$
\mathrm{HC} \text { maintain institutional control }=1
$$

Applying the above factors to the RH equation results in the following RH values for sub-surface contamination risk/hazard management at the site:

$$
\begin{array}{ll}
\text { RH current operations } & =(1.1 \mathrm{E} 8 / 1.1 \mathrm{E} 8)(1000 / 1000)(1 / 1)=1 \\
\text { RH monitoring and management with 70-y decay } & =(4.1 \mathrm{E} 6 / 1.1 \mathrm{E} 8)(1000 / 1000)(1 / 1)=3.7 \mathrm{E}-2
\end{array}
$$

The risk profile table projects the continuance of administrative control with robust groundwater monitoring for the entire 70-year period. Thus, the RT values, as presented in the following plot table, apply and the relationship is plotted in Figure 3.2.

\begin{tabular}{cl} 
RT & \multicolumn{1}{c}{ RH } \\
0.00 & 1.00 \\
70.00 & $3.7 \mathrm{E}-2$
\end{tabular}

\section{Sub-Surface Contamination}

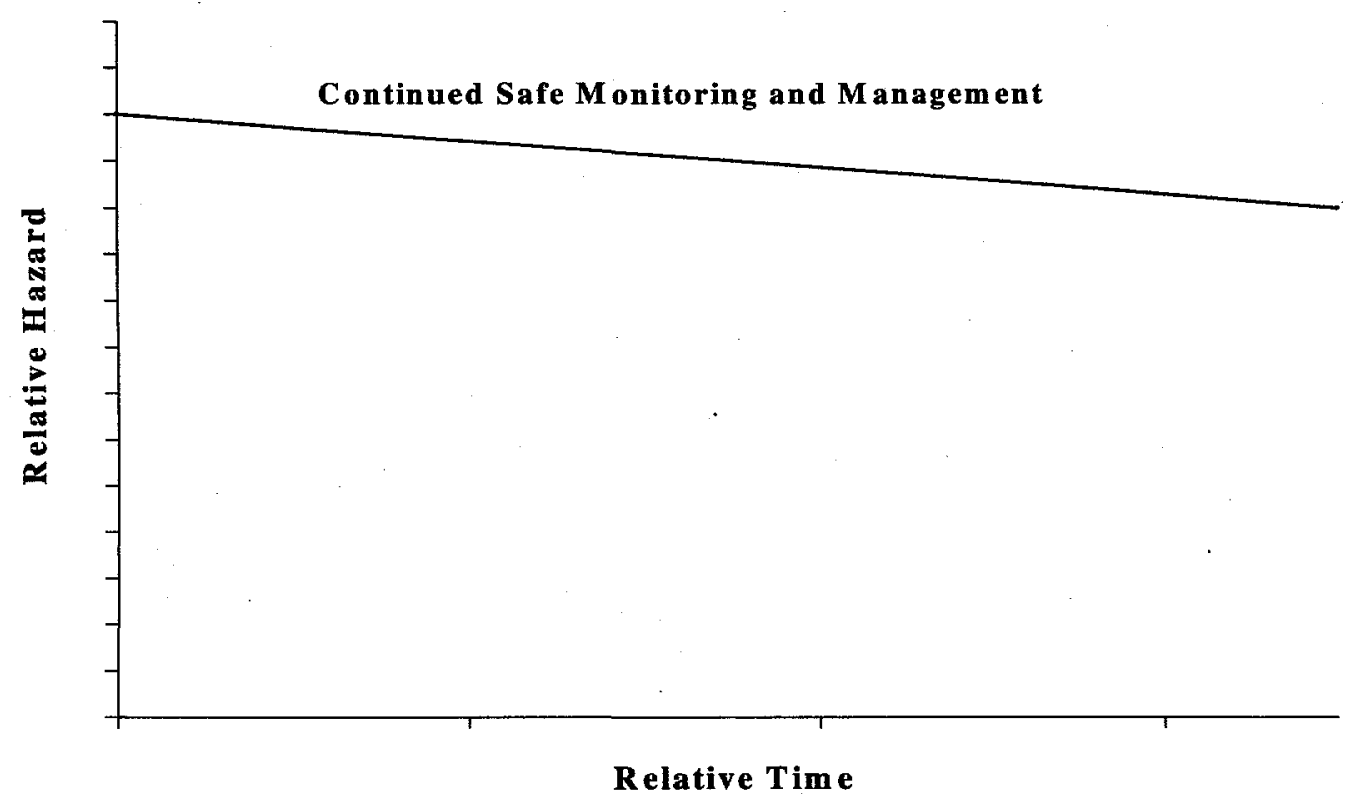

Figure 3.2. Sub-Surface Contamination Calculated for Example Site \#1 


\subsubsection{Waste Disposal Operations Calculation Notes}

The following inventory information for waste disposal operations was received from the site:

$500,000 \quad$ Ci landfills with surface isotopic distribution

1,250 Ci crater subsidence with surface isotopic distribution

$9,000,000$ Ci underground with $89 \%$ tritium and $7.3 \%$ americium assumed

$9,502,250$ Ci total

Thus, $\mathrm{Q}$ current total $=9,502,250 \mathrm{Ci}$.

The estimated surface isotopic distribution is:

$\begin{array}{lc}\text { Isotope } & \text { Percentage } \\ { }^{60} \mathrm{Co} & 1.7 \\ { }^{90} \mathrm{Sr} & 16.1 \\ { }^{137} \mathrm{Cs} & 15.1 \\ { }^{152} \mathrm{Eu} & 7.2 \\ { }^{239} \mathrm{Pu} & 52.4 \\ { }^{241} \mathrm{Am} & 7.3\end{array}$

For the landfills and crater subsidence, a surface isotopic distribution is to be assumed. The surface distribution percentage can be obtained from Table 3.2. The reduction in the mixture (i.e., the landfills and crater subsidence materials) due to 70 years of decay can then be estimated from the initial and 70 -year totals of the table: i.e., $1-(1.3 E 3) / 2042=1.0-0.64=0.36$. The tritium decay can be estimated as $98.1 \%$ over the 70 -year period using the data in Table 3.1, i.e., $(1.01 \mathrm{E} 8-1.95 \mathrm{E} 6) / 1.01 \mathrm{E} 8=98.1 \%$. The americium decay can be estimated as $13.3 \%$ over the 70 -year period using the data in Table 3.2, i.e., $(150-130) / 150=13.3 \%$. This all results in the following decay corrections with resulting 70 -year decayed inventory:

$\begin{array}{ll}\text { Q 70 mix }=501,250 \mathrm{Ci}(0.36) & =180,450 \mathrm{Ci} \\ \text { Q 70 H-3 }=9,000,000 \mathrm{Ci}(0.89)(1-0.981) & =152,190 \mathrm{Ci} \\ \text { Q 70 Am-241 }=9,000,000(0.07)(1-0.133) & =\frac{546,210 \mathrm{Ci}}{8.8 \mathrm{E} 5 \mathrm{Ci}} \\ \text { Total } & \end{array}$

The ${ }^{241} \mathrm{Am}$ isotope was considered to be the controlling constituent for the analysis since it makes up the largest amount of the decayed inventory after the 70-year period (i.e., 546,210 Ci) and has a long halflife. From the HM look-up table for groundwater, ${ }^{241} \mathrm{Am}$ has an HM value of 1,000 .

$$
\mathrm{HM}=1000
$$

Given the isolation, climate, depth-to-groundwater, cover, containment, monitoring, and management of the disposed waste, the site has estimated the worth of the control actions to be roughly four orders of magnitude.

$\mathrm{HC}$ covering and confinement $=\mathrm{E}-4$ 
Applying the above factors to the $\mathrm{RH}$ equation results in the following $\mathrm{RH}$ values for the risk/hazard management actions projected for waste disposal operations:

$$
\begin{array}{ll}
\text { RH current } & =(9.5 \mathrm{E} 6 / 9.5 \mathrm{E} 6)(1000 / 1000)(1 / 1)=1 \\
\text { RH waste receipt, covering and confinement } & =(9.5 \mathrm{E} 6 / 9.5 \mathrm{E} 6)(1000 / 1000)(\mathrm{E}-4 / 1)=1.0 \mathrm{E}-4 \\
\text { RH covering, confinement, and decay } & =(8.8 \mathrm{E} 5 / 9.5 \mathrm{E} 6)(1000 / 1000)(\mathrm{E}-4 / 1)=9.3 \mathrm{E}-6
\end{array}
$$

The risk profile tables show current operations continuing for roughly 8 years with waste receipt, covering, and confinement operations occurring over a 40-year period. Decay was applied over the 70-year analysis period. These time assumptions result in the RT values presented in the following plot table and the relationship plotted in Figure 3.3:

\begin{tabular}{ll}
$\frac{\mathrm{RT}}{0.00}$ & $\mathrm{RH}$ \\
\hline 8.00 & 1.00 \\
40.00 & 1.00 \\
70.0 & $1.00 \mathrm{E}-4$ \\
& $9.30 \mathrm{E}-6$
\end{tabular}

\section{W aste $D$ isposal Operations}

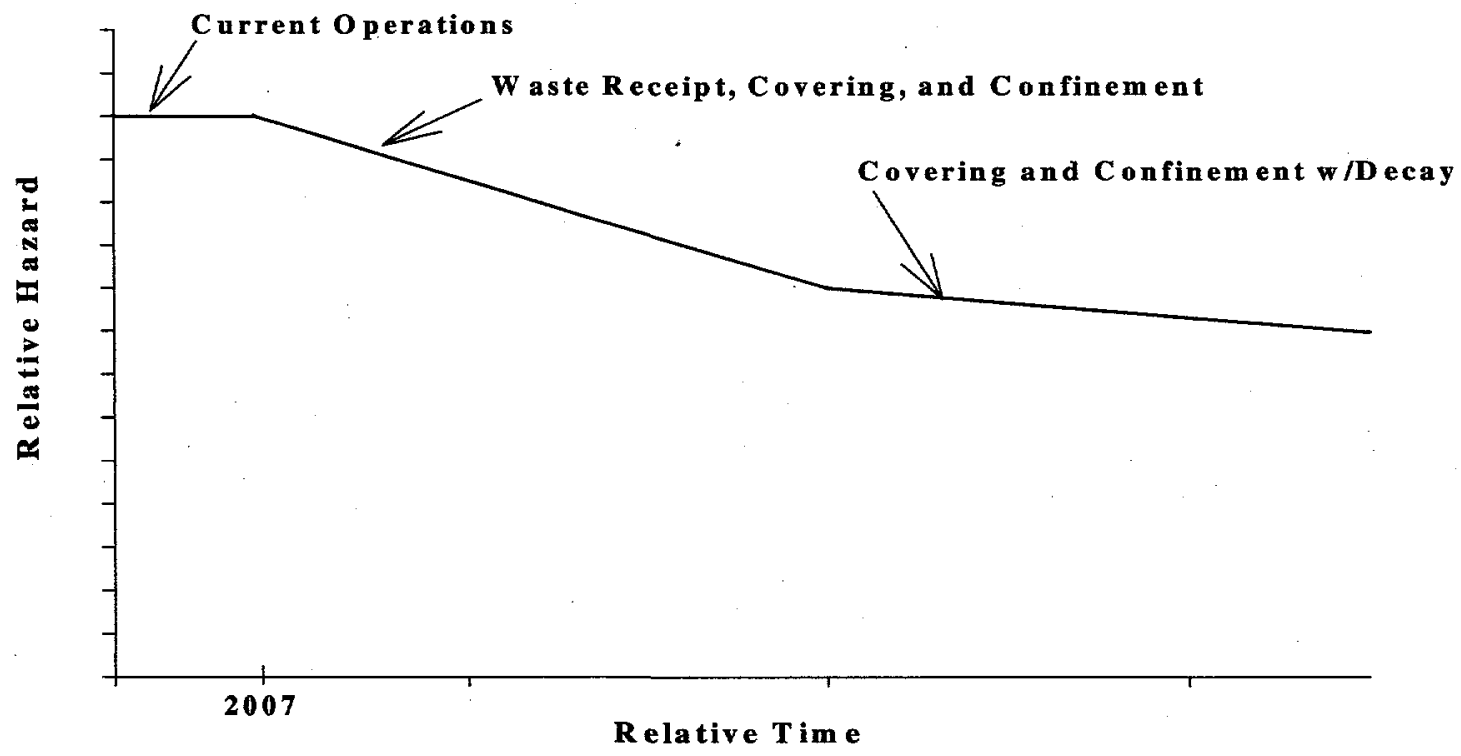

Figure 3.3. Waste Disposal Calculations for Example Site \#1 


\subsubsection{References}

Since the purpose of this analysis is only to serve as an example, the pertinent references are not included; however, documenting the references is an important part of an actual analysis. In past analyses, the inventory information was assembled in a spreadsheet utilizing the reference note capability of the spreadsheet software. This allows documentation of the references from which each specific piece of information/data was obtained. It is also good practice to include a bibliographic list of all the references (cited in the spreadsheet) in the calculation notes.

\subsection{Example Site \#2}

The Example Site \#2 analysis provides a good example of a site with detailed annual source-term quantity data. However, for security reasons, detailed curie-content data were not releasable for all waste types at the site. Thus, the volume data were used in the analysis. These data are less desirable for the analysis because the results will be less comparable across the different waste types. It also necessitates assigning the entire volume of the material to the controlling constituent quantity. This generally produces an overly conservative quantity of the respective constituents. However, since the RH is a ratio, these quantities will balance out for most cases. This overly conservative approach could greatly impact the relative hazard results when risk management actions involve direct modification of part or all of the inventory (e.g, separation, elimination, or reduction of controlling constituents in the total inventory).

The inventories were taken from the site's disposition maps. Specific waste streams within a waste type were consolidated in an effort to roll up the inventories to the highest level that matched the PBS descriptions. Hazard control factors were based on risk evaluations conducted for a site-specific cumulative impact assessment.

\subsubsection{Nuclear Materials Calculation Notes}

The air pathway is assumed to be the controlling pathway.

The initial inventory is the sum of the inventories presented for nuclear materials in the risk profile tables, divided into the categories of solids/sludges and liquids.

$$
\begin{aligned}
& \mathrm{Q}=1.3 \mathrm{E} 4 \mathrm{~kg} \text { solids and sludges } \\
& \mathrm{Q}=1.2 \mathrm{E} 2 \mathrm{~kg} \text { liquids }
\end{aligned}
$$

It was assumed that all of the inventory was releasable to the environment.

$$
\mathrm{RF}=1.0
$$

The plutonium and uranium isotopes were considered to be the controlling constituents for the analysis. Using the HM look-up table for the air pathway, an HM value of 1.0E4 was assigned.

$$
\mathrm{HM}=1.0 \mathrm{E} 4
$$


Based on an internal risk assessment for the site, the site submitted the following $\mathrm{HC}$ values to be considered for the projected risk/hazard management actions:

HC current

$\mathrm{HC}$ solid residue stabilize and repack

HC pits removed from site

HC special nuclear materials (SNM) consolidated

$\mathrm{HC}$ enriched uranium removed from site

HC liquid residue stabilization

HC Pu metal and oxides stabilized, repacked and shipped offsite $=0.005$

HC solid residue stabilized, repacked and shipped offsite
$=1$ (baseline)

$=1.8$ (reflects increase in inventory activity)

$=0.4$

$=0.1$

$=0.05$

$=0.01$

$=0.001$

Applying the above factors to the RH equation results in the following RH values for the various risk/hazard management actions projected for the site:

RH current solid and sludge

RH current liquid

$\mathrm{RH}$ solid residue stabilize and repack

$\mathrm{RH}$ pits removed from site

RH SNM consolidated

RH enriched uranium removed from site

RH liquid residue stabilization

$\mathrm{RH} \mathrm{Pu}$ metal and oxides stabilized, repacked,

and shipped offsite

RH solid residue stabilized, repacked and shipped offsite

$$
\begin{aligned}
= & (1.3 \mathrm{E} 4 / 1.3 \mathrm{E} 4)(1 / 1)(1.0 \mathrm{E} 4 / 1.0 \mathrm{E} 4)(1 / 1)=1 \\
= & (1.2 \mathrm{E} 2 / 1.2 \mathrm{E} 2)(1 / 1)(1.0 \mathrm{E} 4 / 1.0 \mathrm{E} 4)(1 / 1)=1 \\
= & (1.3 \mathrm{E} 4 / 1.3 \mathrm{E} 4)(1 / 1)(1.8 / 1)=1.8 \\
& (1.3 \mathrm{E} 4 / 1.3 \mathrm{E} 4)(1 / 1)(1.0 \mathrm{E} 4 / 1.0 \mathrm{E} 4)(0.4 / 1)=0.4 \\
= & (1.3 \mathrm{E} 4 / 1.3 \mathrm{E} 4)(1 / 1)(1.0 \mathrm{E} 4 / 1.0 \mathrm{E} 4)(0.01 / 1)=0.01 \\
= & (1.3 \mathrm{E} 4 / 1.3 \mathrm{E} 4)(1 / 1)(1.0 \mathrm{E} 4 / 1.0 \mathrm{E} 4)(0.05 / 1)=0.05 \\
= & (1.2 \mathrm{E} 2 / 1.2 \mathrm{E} 2)(1 / 1)(1.0 \mathrm{E} 4 / 1.0 \mathrm{E} 4)(0.1 / 1)=0.1 \\
= & (1.3 \mathrm{E} 4 / 1.3 \mathrm{E} 4)(1 / 1) \\
& (1.0 \mathrm{E} 4 / 1.0 \mathrm{E} 4)(0.005 / 1)=0.005 \\
= & (1.3 \mathrm{E} 4 / 1.3 \mathrm{E} 4)(1 / 1) \\
& (1.0 \mathrm{E} 4 / 1.0 \mathrm{E} 4)(0.001 / 1)=0.001
\end{aligned}
$$

\begin{tabular}{|c|c|}
\hline RT & RH \\
\hline 0.00 & 1.00 \\
\hline 1.00 & 1.00 \\
\hline 1.50 & 1.80 \\
\hline 1.55 & 0.40 \\
\hline 1.70 & 0.10 \\
\hline 3.50 & $5.00 \mathrm{E}-2$ \\
\hline 7.00 & $1.00 \mathrm{E}-2$ \\
\hline 7.80 & $5.00 \mathrm{E}-3$ \\
\hline 20.00 & $1.00 \mathrm{E}-3$ \\
\hline
\end{tabular}

Only a 20-year analysis period was used because the site is schedule to be cleaned up within that period of time. The site provided specific dates for completion of the various risk/hazard management activities, which were converted directly by starting from a 1998 starting point into the RT values shown in the following table and the plot in Figure 3.4: 


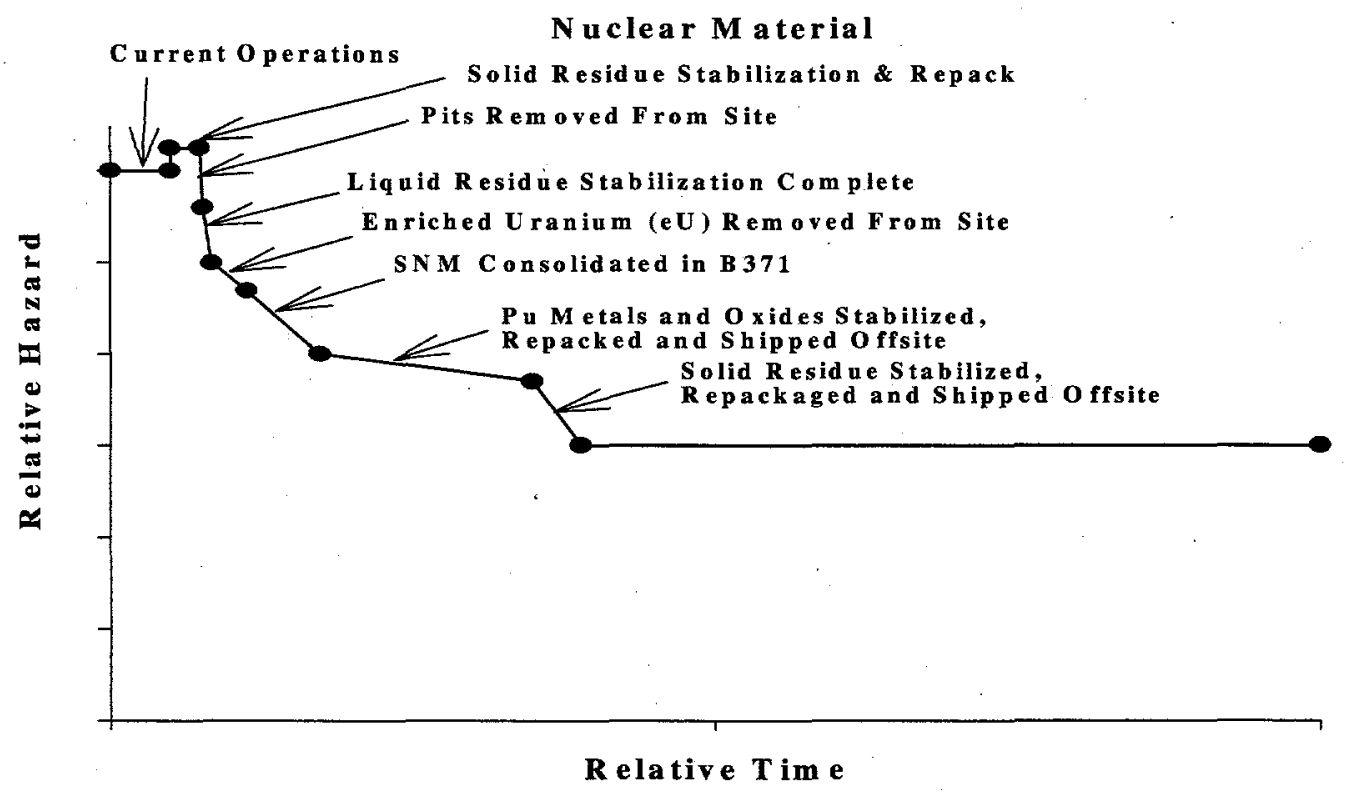

Figure 3.4. Nuclear Material Relative Hazards Calculated for Example Site \#2

\subsubsection{Transuranic Waste Calculation Notes}

The air pathway is assumed to be the controlling pathway.

The total inventory is the sum of the inventories presented for transuranic waste in the risk profile tables.

$$
\mathrm{Q}=9.5 \mathrm{E} 3 \mathrm{~m}^{3}
$$

The site provided the following year-by-year inventory projections through the year 2009 , with running $Q$ values assigned accordingly, which included each year's increase:

\begin{tabular}{|c|c|}
\hline Year & Additional Inventory $\left(\mathrm{m}^{3}\right)$ \\
\hline 1998 & 126 \\
\hline 1999 & 1000 \\
\hline 2000 & 2000 \\
\hline 2001 & 2000 \\
\hline 2002 & 2000 \\
\hline 2003 & 1774 \\
\hline 2004 & 344 \\
\hline 2005 & 157 \\
\hline 2006 & 64 \\
\hline 2007 & 45 \\
\hline 2008 & 14 \\
\hline \multirow{2}{*}{2009} & 9 \\
\hline & $\overline{9.5 \mathrm{E} 3}$ \\
\hline
\end{tabular}


It was assumed that all of the inventory was releasable to the environment.

$$
\mathrm{RF}=1
$$

The plutonium isotopes were considered to be the controlling constituents for the analysis. Using the $\mathrm{HM}$ look-up table for the air pathway, an $\mathrm{HM}$ value of $1.0 \mathrm{E} 4$ was assigned.

$$
\mathrm{HM}=1.0 \mathrm{E} 4
$$

Based on an internal risk assessment for the site, the site submitted the following $\mathrm{HC}$ values to be considered for the projected risk/hazard management actions:

$\mathrm{HC}$ current $=1$ (baseline)

$\mathrm{HC}$ during residue stabilization and decontamination and decommissioning (D\&D) activities $=1$ (actual increases in $\mathrm{RH}$ due to generation, shown as inventory increase)

$\mathrm{HC}$ residue stabilization and $\mathrm{D} \& \mathrm{D}$ complete

$$
=0.0001
$$

Applying the above factors to the $\mathrm{RH}$ equation results in the following $\mathrm{RH}$ values for the various risk/hazard management actions projected for the site:

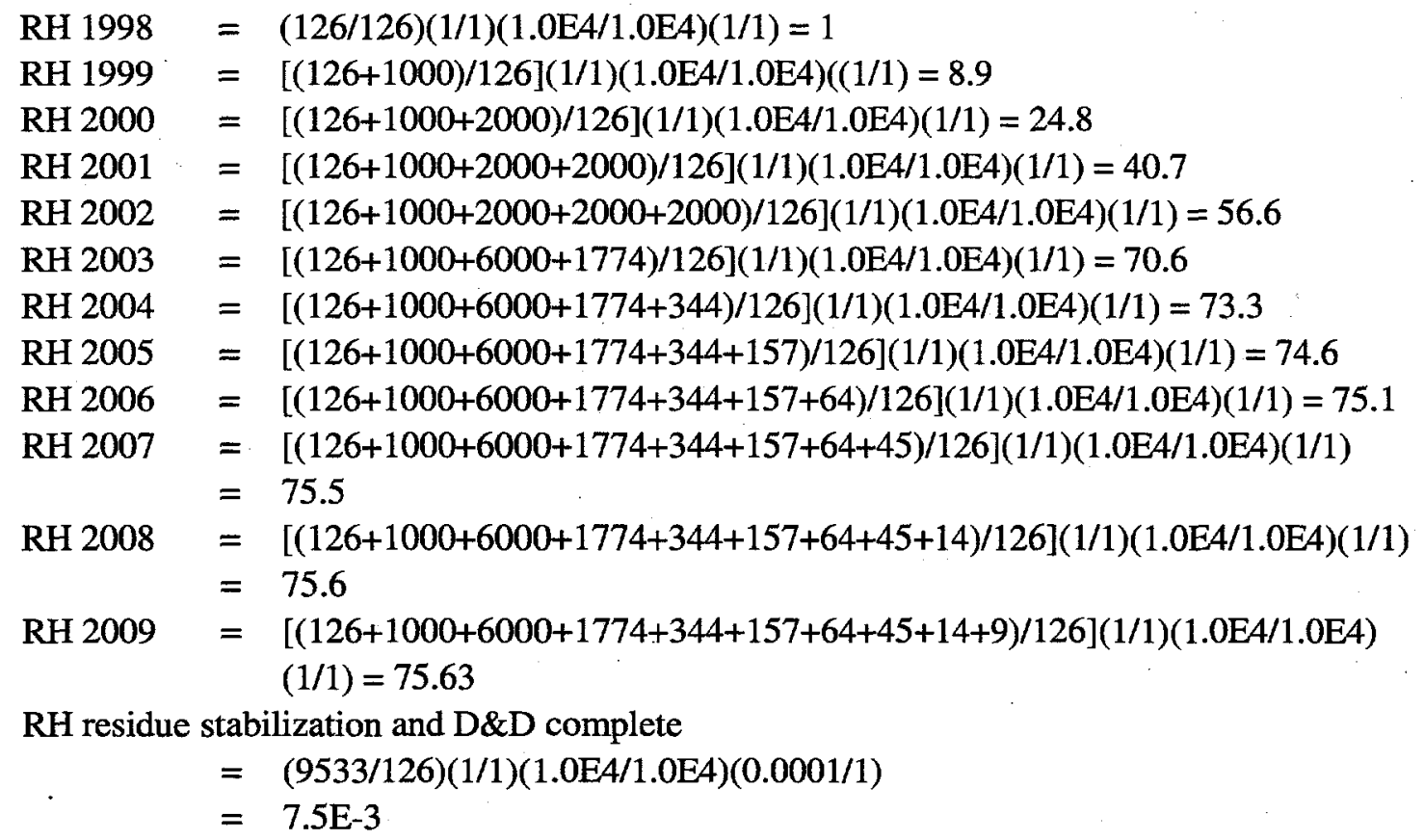

Only a 20-year analysis period was used because the site is scheduled to be cleaned up within that period of time. The individual years associated with each inventory change were used to directly assign RT values, resulting in the following table and the plot in Figure 3.5: 


$\begin{array}{cc}\text { RT } & \text { RH } \\ 0.00 & 1.00 \\ 1.00 & 1.00 \\ 2.00 & 8.90 \\ 3.00 & 24.80 \\ 4.00 & 40.70 \\ 5.00 & 56.60 \\ 6.00 & 70.60 \\ 7.00 & 73.30 \\ 8.00 & 74.60 \\ 9.00 & 75.10 \\ 10.00 & 75.50 \\ 11.00 & 75.60 \\ 12.00 & 75.63 \\ 16 & 0.0075 \\ 20.0 & 0.0075\end{array}$

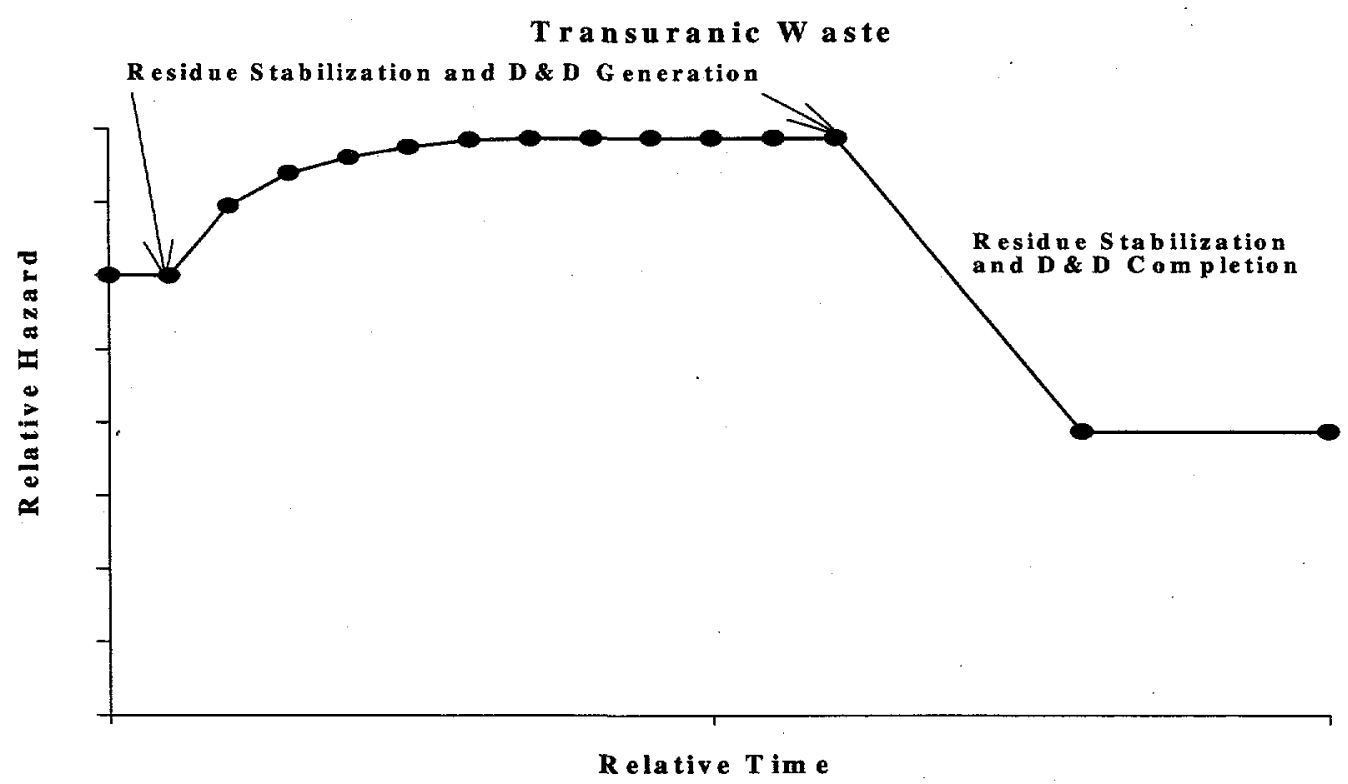

Figure 3.5. Transuranic Waste Relative Hazards Calculated for Example Site \#2

\subsubsection{Low-Level Waste and Mixed Low-Level Waste Calculation Notes}

The surface water pathway is assumed to be the controlling pathway.

The total inventory is the sum of the inventories presented for low-level waste (LLW) and mixed lowlevel waste (MLLW) in the risk profile tables. 


$$
\mathrm{Q}=3.5 \mathrm{E} 5 \mathrm{~m}^{3}
$$

The site provided the following year-by-year inventory projections through the year 2020 , with $Q$ values for each year assigned accordingly:

\begin{tabular}{|c|c|}
\hline Year & Inventory $\left(\mathrm{m}^{3}\right)$ \\
\hline 1998 & 7118 \\
\hline 1999 & 9250 \\
\hline 2000 & 6800 \\
\hline 2001 & 18899 \\
\hline 2002 & 12635 \\
\hline 2003 & 13149 \\
\hline 2004 & 14043 \\
\hline 2005 & 13309 \\
\hline 2006 & 12647 \\
\hline 2007 & 12234 \\
\hline 2008 & 12224 \\
\hline 2009 & 11977 \\
\hline 2010 & 11977 \\
\hline 2020 & $\underline{11977}$ \\
\hline & $3.5 \mathrm{E} 5$ \\
\hline
\end{tabular}

It was assumed that all of the inventory was releasable to the environment.

$$
\mathrm{RF}=1
$$

The plutonium and uranium isotopes were considered to be the controlling constituents for the analysis. Using the HM look-up table for the surface water pathway, an $\mathrm{HM}$ value of 1.0E3 was assigned.

$$
\mathrm{HM}=1.0 \mathrm{E} 3(\mathrm{Pu} \text { and } \mathrm{U} \text { isotopes, } 100 \mathrm{nCi} / \mathrm{g} \text { controlling constituents) }
$$

Based on an internal risk assessment for the site, the site submitted the following $\mathrm{HC}$ values to be considered for the projected risk/hazard management actions:

$$
\begin{array}{ll}
\mathrm{HC} \text { current } & =1 \text { (baseline) } \\
\mathrm{HC} \text { D\&D completion } & =1.0 \mathrm{E}-3
\end{array}
$$

Applying the above factors to the RH equation results in the following $\mathrm{RH}$ values for the risk/hazard management actions projected for the site:

$$
\begin{array}{ll}
\text { RH } 1998 & =(7118 / 7118)(1 / 1)(1.0 \mathrm{E} 3 / 1.0 \mathrm{E} 3)(1 / 1)=1 \\
\text { RH 1999 } & =(9250 / 7118)(1 / 1)(1.0 \mathrm{E} 3 / 1.0 \mathrm{E} 3)(1 / 1)=1.3 \\
\text { RH 2000 } & =(6800 / 7118)(1 / 1)(1.0 \mathrm{E} 3 / 1.0 \mathrm{E} 3)(1 / 1)=0.96
\end{array}
$$




$\begin{array}{ll}\text { RH 2001 } & =(18899 / 7118)(1 / 1)(1.0 \mathrm{E} 3 / 1.0 \mathrm{E} 3)(1 / 1)=2.65 \\ \text { RH 2002 } & =(12635 / 7118)(1 / 1)(1.0 \mathrm{E} 3 / 1.0 \mathrm{E} 3)(1 / 1)=1.77 \\ \text { RH 2003 } & =(13149 / 7118)(1 / 1)(1.0 \mathrm{e} 3 / 1.0 \mathrm{E} 3)(1 / 1)=1.84 \\ \text { RH 2004 } & =(14043 / 7118)(1 / 1)(1.0 \mathrm{E} 3 / 1.0 \mathrm{E} 3)(1 / 1)=1.97 \\ \text { RH 2005 } & =(13309 / 7118)(1 / 1)(1.0 \mathrm{E} 3 / 1.0 \mathrm{E} 3)(1 / 1)=1.87 \\ \text { RH 2006 } & =(12647 / 7118)(1 / 1)(1 / 0 \mathrm{E} 3 / 1.0 \mathrm{E} 3)(1 / 1)=1.77 \\ \text { RH 2007 } & =(12234 / 7118)(1 / 1)(1.0 \mathrm{E} 3 / 1.0 \mathrm{E} 3)(1 / 1)=1.71 \\ \text { RH 2008 } & =(12224 / 7118)(1 / 1)(1.0 \mathrm{E} 3 / 1.0 \mathrm{E} 3)(1 / 1)=1.71 \\ \text { RH 2009 } & =(11977 / 7118)(1 / 1)(1.0 \mathrm{E} 3 / 1.0 \mathrm{E} 3)(1 / 1)=1.69 \\ \text { RH 2010 } & =(11977 / 7118)(1 / 1)(1.0 \mathrm{E} 3 / 1.0 \mathrm{E} 3)(1.0 \mathrm{E}-3 / 1)=1.69 \mathrm{E}-3 \\ \text { RH 2020 } & =(11977 / 7118)(1 / 1)(1.0 \mathrm{E} 3 / 1.0 \mathrm{E} 3)(1.0 \mathrm{E}-3 / 1)=1.69 \mathrm{E}-3\end{array}$

Only a 20-year analysis period was used because the site is scheduled to be cleaned up within that period of time. The individual years associated with each inventory were used to directly assign RT values, resulting in the following table and the plot in Figure 3.6:

\begin{tabular}{cc} 
RT & \multicolumn{1}{c}{ RH } \\
0.00 & 1.00 \\
1.00 & 1.00 \\
2.00 & 1.30 \\
3.00 & 0.96 \\
4.00 & 2.65 \\
5.00 & 1.77 \\
6.00 & 1.84 \\
7.00 & 1.97 \\
8.00 & 1.87 \\
9.00 & 1.77 \\
10.00 & 1.71 \\
11.00 & 1.71 \\
12.00 & 1.69 \\
13.0 & $1.69 \mathrm{E}-3$ \\
23.0 & $1.69 \mathrm{E}-3$
\end{tabular}


Low Level and Low Level Mixed Waste

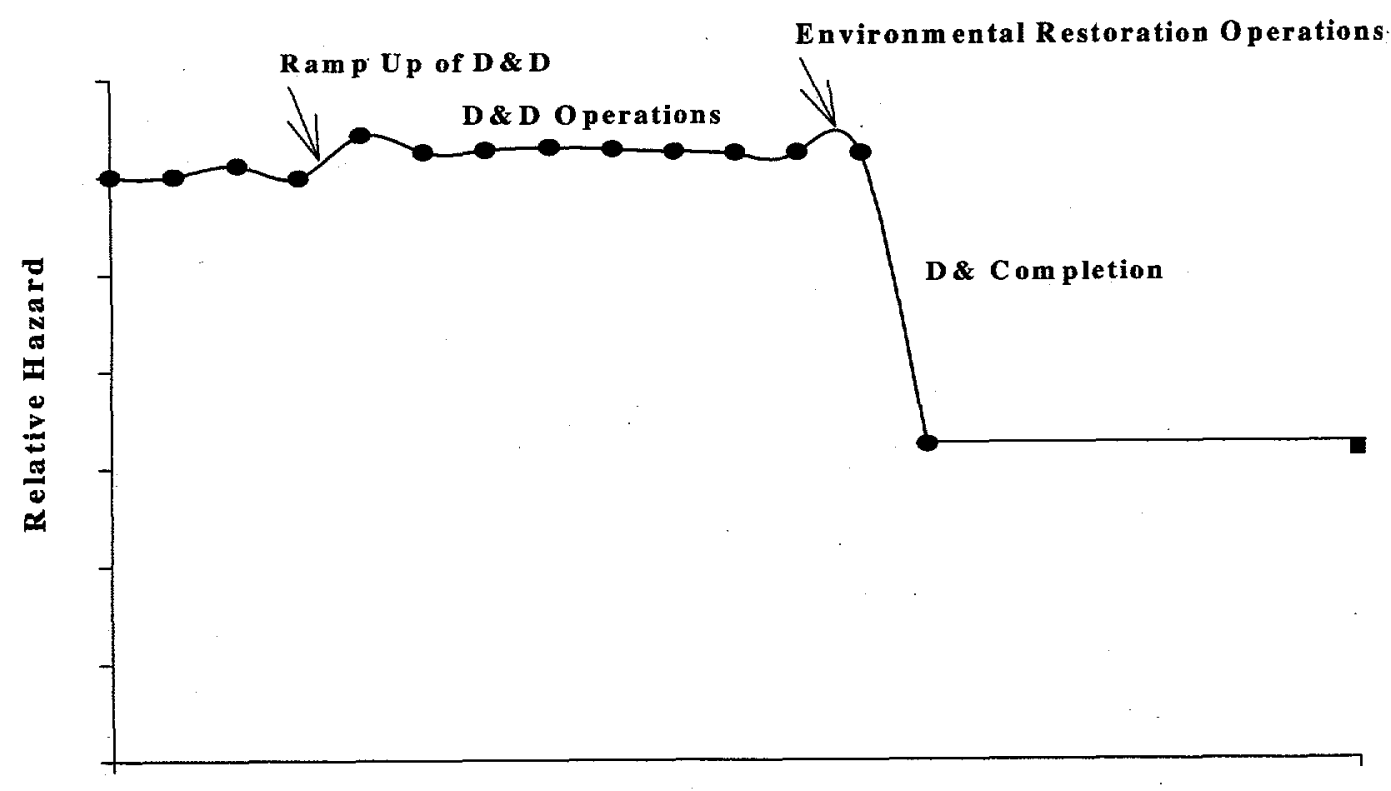

Relative Time

Figure 3.6. LLW and LLMW Relative Hazards Calculated for Example Site \#2 


\subsection{Summary}

The methodology presented in this document was developed to provide a means of calculating the $\mathrm{RH}$ ratios to use in developing useful graphic illustrations. The RH equation, as presented in this methodology, is primarily a collection of key factors relevant to understanding the hazards and risks associated with projected risk management activities. The RH equation has the potential for much broader application than generating risk profiles. For example, it can be used to compare one risk management activity with another, instead of just comparing it to a fixed baseline as was done for the risk profiles. If the appropriate source term data are available, it could be used in its non-ratio form to estimate absolute values of the associated hazards. These estimated values of hazard could then be examined to help understand which risk management activities are addressing the higher hazard conditions at a site. Graphics could be generated from these absolute hazard values to compare high-hazard conditions. If the RH equation is used in this manner, care must be taken to specifically define and qualify the estimated absolute hazard values (e.g., identify which factors were considered and which ones tended to drive the hazard estimation). 


\subsection{References}

40 CFR 302, U.S. Environmental Protection Agency, Designation of Hazardous Substances. 1989. Code of Federal Regulations.

Buck, J.W., L.M. Bagaasen, M.P. Bergeron, G.P. Streile, L.H. Staven, K.J. Castleton, G.M. Gelston, D.L. Strenge, K.M. Krupka, R.J. Serne, and T.A. Ikenberry. 1997. Analysis of the Long-Term Impact of TRU Waste Remaining at Generator Sites for No Action Alternative 2. PNL-11251, Pacific Northwest National Laboratory, Richland, Washington.

Droppo, J.G., Jr. D. L. Strenge, J. W. Buck, B. L. Hoopes, R.D. Brockhaus, M. B. Walter, and G. Whelan. 1989. Multimedia Environmental Pollutant Assessment System (MEPAS) Application Guidance Volume 1-User's Guide. PNL-7216, Pacific Northwest Laboratory, Richland, Washington.

Hawley, K.A., and B.A. Napier. 1985. A Ranking System for Mixed Radioactive and Hazardous Waste Sites in U.S. DOE. Proceedings of the Fifth DOE Environmental Protection Information Meeting. CONF841187, Volume 1. Proceedings of a conference held in Albuquerque, New Mexico, November 6-8, 1984. U.S. Department of Energy, Washington, D.C.

Hawley, K.A., R.A. Peloquin, and R.D. Stenner. 1986. Modified Hazard Ranking System for Sites with Mixed Radioactive and Hazardous Wastes - User Manual. PNL-5841, Pacific Northwest Laboratory, Richland, Washington.

Holdren, G.R., C.S. Glance, L.K. Berg, K. Kelinger, C.J. Fosmire, S.M. Goodwin, J.R. Rustad, R. Schalla, and J.A. Schramke. 1995. Environmental Settings for Selected U.S. Department of Energy Installations - Support Information for the Programmatic Environmental Impact Statement and the Baseline Management Report. PNNL-10550, Pacific Northwest National Laboratory, Richland, Washington.

International Commission on Radiological Protection (ICRP). 1959. Report of Committee II on Permissible Dose for Internal Radiation. International Commission on Radiological Protection, Publication 2, Pergamon Press, New York.

International Commission on Radiological Protection (ICRP). 1979. Limits for Intakes of Radionuclides by Workers. International Commission on Radiological Protection, Publication 30, Pergamon Press, New York.

Napier, B.A., R.A. Peloquin, D.L. Strenge, and J.V. Ramsdell. 1988a. Conceptual Representation. Vol. 1, of GENII - The Hanford Environmental Radiation Dosimetry Software System. PNL-6584, Pacific Northwest Laboratory, Richland, Washington. 
Napier, B.A., R.A. Peloquin, D.L. Strenge, and J.V. Ramsdell. 1988b. User's Manual. Vol. 2, of GENII - The Hanford Environmental Radiation Dosimetry Software System. PNL-6584, Pacific Northwest Laboratory, Richland, Washington.

Napier, B.A., R.A. Peloquin, D.L. Strenge, and J.V. Ramsdell. 1988c. Code Maintenance Manual. Vol. 3 GENII - The Hanford Environmental Radiation Dosimetry Software System. PNL-6584, Pacific Northwest Laboratory, Richland, Washington.

Pacific Northwest National Laboratory (PNNL). 1996. Remedial Action Assessment System (RAAS) Version 1.1. PNL-8751, Rev. 3, Pacific Northwest National Laboratory, Richland, Washington.

Serne, R.J., and M.I. Wood. 1990. Hanford Waste-Form Release and Sediment Interaction. PNL-7297, Pacific Northwest Laboratory, Richland, Washington.

Strenge, D.L., and S.R. Peterson. 1989. Chemical Data Base for the Multimedia Environmental Pollutant Assessment System (MEPAS), Version 1. PNL-7145, Pacific Northwest Laboratory, Richland, Washington.

Stenner, R.D., R.A. Peloquin, and K.A. Hawley. 1986. Modified Hazard Ranking System/Hazard Ranking System for Sites with Mixed Radioactive and Hazardous Wastes - Software Documentation. PNL-6066, Pacific Northwest Laboratory, Richland, Washington.

U.S. Department of Energy (DOE). 1998a. Richland Operations Office: Risk Prospectus - Hanford Site. U.S. Department of Energy, Center for Risk Excellence, Argonne, Illinois.

U.S. Department of Energy (DOE). 1998b. Nevada Operations Office: Human Health and Safety Risk Summary - Nevada Test Site and Off-Site Test Areas. U.S. Department of Energy, Center for Risk Excellence, Argonne, Illinois.

U.S. Department of Energy (DOE). 1998c. Rocky Flats Field Office: Risk Summary-Rocky Flats Environmental Technology Site. U.S. Department of Energy, Center for Risk Excellence, Argonne, Illinois.

U.S. Department of Energy (DOE). 1998d. Savannah River Operations Office:" Risk Summary Savannah River Site. U.S. Department of Energy, Center for Risk Excellence, Argonne, Illinois.

U.S. Department of Energy (DOE). 1998e. Albuquerque Operations Office: Risk Summary - Pantex Plant, Sandia National Laboratories and Los Alamos National Laboratory. U.S. Department of Energy, Center for Risk Excellence, Argonne, Illinois.

U.S. Environmental Protection Agency (EPA). 1982. Uncontrolled Hazardous Waste Site Ranking System, Appendix A, Subpart H of the National Oil and Hazardous Substance Contingency Plan. U.S. Environmental Protection Agency, Federal Register 31219-31243 (July 16, 1982). 
Warren, B.R., and D.L. Strenge. 1994. Multimedia-Modeling Environmental Database and Editor (MMEDE): User Manual. PNNL-11562, Pacific Northwest National Laboratory, Richland, Washington. 
Rev. 0

\section{Distribution}

No. of

Copies

\section{OFFSITE}

M. Gilbertson

DOE-EM

EM-52
No. of

Copies

ONSITE

52 Pacific Northwest National Laboratory

W. B. Andrews

K7-10

W. J. Martin

K3-54

R. D. Stenner (50)

Distr.1 